\title{
Giambattista Vico's philosophy of order
}

In his well-known study La Crise de la Conscience Européenne, Paul Hazard assigns a singular place to the Italian philosopher Giambattista Vico (1668-1744), especially for the radically new vision developed in the $\mathrm{New}$ Science, a work which underwent constant revisions till the author's death 1 . In Hazard's judgement, Vico's thought is new for three reasons: it concerns the prehistory, examines the beginnings of human culture and thereby proposes a theory of self-assertion of $\operatorname{man}^{2}$. Of special interest in the philosophical anthropology of the New Science is its emphasis on phantasy, source and motor of all transition from brute to human existence. The preeminence attributed to phantasy also serves Vico to criticize the rationalistic positions advanced by René Descartes (1596-1650), to attack the model of society represented by Thomas Hobbes (1588-1679) and above all to propose a commonwealth in many aspects akin to, but in its birth and growth essentially different from the Republic of Plato. How and to what extent the New Science deviates from previous anthropologies, social and political theories, what precisely does Vico's thought contribute to the contemporary philosophy, etc. are some of the issues to be discussed in this essay. However, it approaches the philosophy of Vico from a novel perspective, namely that of order.

Why 'order'? Ordo or order constitutes a key notion of ancient and medieval thought both in theology and philosophy, a uniquely privileged concept to interpret $\mathrm{Vico}^{3}$. Among the studies in the twentieth century since Benedetto Croce's La filosofia di Giambattista Vico (1911), a high-handed presentation of Vico's philosophy in the veneer of New Hegelianism, there have been various successful attempts to liberate it from partisan alliance.

1. The New Science of Vico had three revised editions, in 1725, 1730 and 1744. Commonly known as Scienza nuova prima, the first edition, Principi di una scienza nuova intorno alla natura delle nazioni per la quale si ritruovano i principi di altro sistema del diritto naturale delle genti, contrasts both in content and structure with the later editions, which hence were called Scienza nuova seconda.

2. Paul Hazard, Die Krise des europäischen Geistes (Hoffmann \& Campe, Hamburg 1939), p. 487.

3. Compare Peter G. Pandimakil, Das Ordnungsdenken bei Giambattista Vico (Peter Lang, Frankfurt a. M. 1995). This essay develops further the main points discussed herein. 
This welcome turn not to brand Vico's thought as Catholic, Platonic, Marxian, etc. has however generated the question: what sort of philosophy Vico espouses after all? Where does its importance lie? Is it philosophical anthropology, liberal humanism, sociology of knowledge, pre-Kantian transcendental thought, rhetoric, politics, ethics, aesthetics, etc.? Undoubtedly one finds enough material in the works of Vico to substantiate any of these claims. And all such readings of Vico's thought are extremely useful, for Vico offers new insights in modern problems. However, it is unlikely that Vico's own thought lacks that unitive character, which he finds in the primitive thought thanks to an autopoietic phantasy. A close examination of the origin and development of the primitive thought as presented in the New Science shows that Vico traces the ancient and medieval concept of order to the autopoietic phantasy which humanises and organizes the society, and in consequence there emerges a commonwealth. Thus the concept of order unifies the apparently discordant facets in Vico's thought, its essentially theological and philosophical trends, both of which necessarily complement each other.

In the following pages I discuss (I) the concept of order till Vico. The task is to trace and situate the patterns of thought which Vico utilizes as well as transforms in creating a philosophical anthropology based on autopoietic phantasy. Due to the vastness and complexity of the problematics of order in ancient and medieval thought, the analysis will have to limit itself to select authors and themes. In pursuing the transition from the cosmocentric to anthropocentric thought, we shall come upon the immediate background of Vico's reflection: the Renaissance philosophy. Vico's role in it is defined both by comparison and contrast to Marsilio Ficino, Giovanni Pico della Mirandola and Giordano Bruno. An important issue of the Renaissance philosophy, namely the nature of human self-assertion, will constitute the corner stone of (II) Vico's anthropology developed in the New Science. However, Vico cannot be adequately understood or explained merely on the basis of this last work despite its excellence. Almost all the arguments arrayed in the New Science appear in the Diritto Universale ${ }^{4}$, which illustrates the theologicalmetaphysical grounds of Vico's philosophy. Nonetheless Vico departs from some of the positions taken here, applying in the New Science with greater success the 'ingenious method' developed in Liber metaphysicus. The concept of order acquires thereby a cognitive dimension, which, I think, is essential for understanding the simultaneous genesis of idea and of society. Both in the

4. This Italian title stands commonly for the following three volumes in Latin: De universi iuris uno principio et fine uno; De constantia iurisprudentis; \& Notae, published in 1720-1722. 
birth and development of humanity the self-fabricated image of God plays a decisive role: it is this idea which binds the humans to a life-style, engendering the institutions of religion, marriage and burial. Constancy in thought is coupled with constancy in manners: belief and action go together and determine mutually. It is however necessary to ask (III) how and to what extent the ingenious conception of human beginnings in the New Science offers us any help in comprehending the contemporary society. Vico offers an interpretation of universal history in terms of corsi e ricorsi, which according to many scholars underestimates the concept of progress. However, considerable similarities to Vico's concept of society can be found not only in the writings of Norbert Elias and Jürgen Habermas, but also in those of Auguste Comte. Whatever a comparative study of Vico with modern thinkers might bring forth, Vico's best legacy seems to lie in the theory of autopoiesis, in the spontaneous creativity attributed to fantasia in constituting what is human. This might offer the key to Vico's notion of progress, which is never unlimited nor fully susceptible to human design. From this perspective the political ethics of the New Science warns the humanity of the danger inherent in the socio-political system of liberty, equality and enlightenment. However, the fragility of human institutions should not dissuade man's progress, for to be conscious of the limits amounts to overcoming them.

\section{THE CONCEPT OF ORDER IN THE ANCIENT, MEDIEVAL AND RENAISSANCE PHILOSOPHY}

A brief review of the notion of order in the philosophy till the seventeenth century enables us not only to situate Vico in the history of ideas but also to recognize the conceptual continuity in thought. Among the many expressions used to indicate order the two terms taxis and kósmos require special attention5. For they, in spite of their multiple significance, offer us in a nutshell the various conceptions of order in the ancient thought. Both the medieval and Renaissance philosophy preserve the ancient ideas, although each period interprets them to its advantage. As a consequence the philosophy of

5. For an introductory discussion, see "Ordnung", in: Historisches Wörterbuch der Philosophie (ed. Joachim Ritter \& Karlfried Gründer, Scwabe \& Co. AG., Basel/Stuttgart, since 1971), vol. 6, col. 1250-1309. 
order opens up new dimensions in defining man's place in the universe. If the concept of order served the ancients to consider man as part of the universe, the medieval thinkers utilized it to specify man's place therein: it is in a divinely ordered universe that man has his proper place. But does not the introduction of God in the universe threaten human freedom? The Renaissance thought seems to answer this question by setting man in the place of God. This however originates a new problem: can the universal order be sustained without the 'divinely ordered' hierarchy? Is there any room for human self-assertion without depriving God of his place? These philosophical-theological problematics constitute the immediate background of Vico's thought. Hence the inevitability of a discussion of the philosophy of order till Vico.

\section{I.1. The beginnings of a philosophy of order}

A rapid historical review of the ancient philosophy of order can profitably begin, as suggested, with a study of the concepts of taxis and kósmos. In the ancient thought there is no uniform conception of order, as a result there exists more than one expression for what is commonly understood as order ${ }^{6}$. The term kósmos summarizes adequately the pre-Socratic conception of order, while taxis, a term with normative implications, expresses succinctly the additional sense often attributed to it among the Pythagoreans. Both terms, however, are interchangeable and employed variously in contemporary language?

Premonitions of the concept of order, both in the notion and use of the word kósmos, can be traced in Hesiod's works. Differentiating kósmos against chaos, describing the rank and just order among the gods he paves the way for the Milesian thinkers to conceive the universe as a whole. It is Anaximander (c. 610-545 BC) who first advances the notion of kósmos as a totality of parts. Unlike Hesiod or Homer, Anaximander considers the parts

6. See on this point the extensive study of Walther Kranz, "Kosmos", in: Archiv für Begriffsgeschichte, $2 / 1$ (1955) 5-113 \& 2/2 (1957) 115-266.

7. Kósmos denotes both visible, external and invisible, internal order, for example a tectonic building, adornments, structured army, ordered society and a mannered person. Its meaning covers military, political, ethical and aesthetical realms including social and individual behaviour. One encounters especially in the military sphere the term taxis, substituting kósmos. It is then supposed to indicate a particular form of order wherein each one has a fixed place. Compare Jula Kerschensteiner, Kosmos: Quellenkritische Untersuchungen zu den Vorsokratikern (München, 1962), pp. 4ff.; Hermann Sasse, "Kosméo, kósmos, kósmios, kosmikós”, in: Theologisches Wörterbuch zum Neuen Testament (ed. Gerhard Friedrich, Kohlhammer, Stuttgart-Berlin-Köln-Mainz, 1938), vol. 3, pp. 867-898. 
of the universe not as juxtaposed, but as intertwined or concatenated. Kósmos would mean then an interlaced, structured, harmonious whole constituted of earth, oceans, air and fire. It is this universe, the ordered unity, which he names ouranos. Anaximander also postulates universes - ouranoi which in timely succession emerge and pass away ${ }^{8}$. These universes comprise of kosmoi: tectonic structures within the ouranoi. As a result the emergence of the world is identical with the appearance of the kosmoi, which in their structural unity represent the universe ${ }^{9}$. Spatial as well as temporal notions are implied in this conception. Kósmos is an organic whole, a living totality susceptible to cyclical changes. Applied to the world the term denotes for Anaximander a well - ordered unity - a conception that borders on a social set-up based on norms and to a certain extent presages Plato.

Further development of the concept of order is found in Heraclitus (c. 550-480) who defines kósmos against eike $e^{10}$ and advances the notion of an immanent but invisible order. With this notion Heraclitus does not introduce an abstract concept but interprets the still materially conceived arche, fire, as the ultimate reality encompassing the universe and rendering order. Heraclitus' kósmos, alike Anaximander's, is constituted of tectonically structured parts (earth, ocean and air) but unlike Anaximander, Heraclitus maintains that all things come into being in exchange of fire: the reality as a result is nothing but ever-living fire ${ }^{11}$. As principle of unity this fire is called also logos and made equivalent to kósmos. Everything occurs according to logos; it hence can be said to be the common: xinon, which guarantees the eternal world order. In fact, logos and kósmos are two aspects of xinon. For Heraclitus this would also signify the divine law which governs the world and is known by the 'awake'. And everything falls under the law of $\log o s^{12}$.

Perhaps the advancement against Anaximander and the novelty in Heraclitus' conception are best evident in his doctrine concerning the law of the

8. Hermann Diels, Die Fragmente der Vorsokratiker (ed. Walter Kranz, Rowohlt, DublinZürich, 1972), vol. 1, 12 B1.

9. I follow here J. Kerschensteiner, Kosmos: Quellenkritische Untersuchungen zu den Vorsokratikern, pp. $37 \mathrm{ff}$. Slightly different, but to our present purpose discountable, is the interpretation of Charles H. Kahn, Anaximander and the Origins of Greek Cosmology (Columbia Press, N. Y., 1960), pp. 178-193.

10. Fragment B 124 (cf. H. Diels, Die Fragmente der Vorsokratiker) postulates: ôsper sárma eiké kechuménon ó kállistos [ó] kósmos = The best cosmos is like its opposite: an assembly of things thrown together at random.

11. Fragments B $30,31 \& 90$.

12. Fragments B 1, 2, 41, 94 \& 114. Also: J. Kerschensteiner, Kosmos: Quellenkritische Untersuchungen zu den Vorsokratikern, pp. $108 \mathrm{f}$. 
opposites and the coincidentia oppositorum, according to which the kósmos is represented by a strung bow. If kósmos were to mean harmony, it is for Heraclitus »the very reverse of the Pythagorean«. Not only should the opposites exist but also do the opposing tensions constitute the kósmos and sustain the universe. "Rest, cessation of effort, would mean the opposite of kósmos, for it would result in the falling apart of the opposites, whose union in an 'adjustment of opposite tensions' -locked, as it were, in an internecine struggle- is what keeps in being the world as we know it «13. The core of Heraclitus' doctrine of opposites is the new ontological insight it brought with: To the sensible universe underlies a dynamism of opposites, not a multiplicity of polar qualities. The world, he would say, »is not the totality of things but of events or facts $\ll^{14}$. Heraclitus views the nature and its phenomena under a single aspect of the being in which regularity and inner unity come to the forefront. Kósmos would then signify the sum total of external and internal world, in all its meaningful, intelligent forms. Kósmos denotes now, more than a tectonic structure, an all-encompassing order, whose principle does not yet transcend the materiality.

Although a non-material principle of order is envisioned only with Plato, the pre-Socratic thought refines the hitherto discussed philosophy of order on the one hand by introducing the concept of archai and on the other by differentiating between material and trans-material forces. The Milesian theory of a single arche is substituted with that of archai, in consonant with the Eleatic notion of being. According to Empedocles (c. 492-432 BC) the union and dissolution of the four basic elements -air, fire, earth and water- under the influence of philia and neikos explain the genesis and disappearance of all things. Kósmos would mean not a permanent, but a temporary state of things held together by philia; it denotes a spatial-material structure different from the forces acting in/on it. Similar is also the kósmos according to Anaxagoras (c. 500-428), but constituted of numerous qualitatively distinct spermata

13. W. K. C. Guthrie, A History of Greek Philosophy (Cambridge University Press, Cambridge 1962), vol. 1, p. 449.

14. Karl R. Popper, The Open society and Its Enemies (Routledge \& Kegan Paul, London, 19845), vol. 1, p. 205. According to Popper Heraclitus' philosophy (»a somewhat typical reaction to the social revolution which he witnessed «, ibid., p. 204) is original especially on two points: the introduction of the concept of process and the discovery of regularity in the processes of Nature: »But having reduced all things to flames, to processes, like combustion, Heraclitus discerns in the processes a law, a measure, a reason, a wisdom; and having destroyed the cosmos as an edifice, and declared it to be a rubbish heap, he re-introduces it as the destined order of events in the world-process« ibid., p. 14. 
which are acted upon by a mental force, nous. Nous is the author both of movement and order. The initial world-stuff attains a final form due to the planned workings of nous. With this notion Anaxagoras qualifies himself as a worthy precursor to Plato ${ }^{15}$. However, it is the atomists who require special attention. For with the introduction of the notion of empty space, they offer an original principle of order: spontaneity, even though it is merely mechanically conceived in this early stage. Kósmos would mean the totality engendered through spontaneous atomic concatenation. Like everything else in this universe, man, constituted of atoms, has only that much liberty accorded to him as he is part of the universe which is ordered and governed by its own laws. Alike the universe, he too is kósmos: antropos mikros kósmos ${ }^{16}$. Also the Pythagoreans subscribe to this privileged position of man.

Even if Pythagoras (570-496 BC) might not have employed the term kós$\operatorname{mos}^{17}$, the attempt to interpret his theory of harmonia in terms of the prevalent conception of kósmos attests to the significance attached to it. Besides this relationship with the traditional philosophy, the Pythagoreans apply the concept of order to the realm of the living. Taxis or order transcends corporeality, it is through ordered behaviour that the soul attains virtue (areté). The term kósmos appears in this connection as that which holds the world, humans and gods together. It is community, friendship, decorous behaviour, inner harmony and sense of justice ${ }^{18}$. This ethico-political notion of order known to Archytas has surely influenced the Platonic conception.

The conception of order offered in Timaios 28bf. is a synthesis of ancient views, elaborated and completed with Plato's own theory of Ideas. Plato describes the genesis of a kósmos out of ataxia through the work of a demiurge. In order to obtain the best result, the task is assigned to the world-soul which out of the four elements forms the sphere-like kósmos, consisting of gods, men, animals, plants and inert matter. It is modelled after the perfect Idea and like it should be consummate, zoon. With this version of the world-order Plato intends to solve the problem of one and the many and to correct the the-

15. Compare Gregory Vlastos, "The Physical theory of Anaxagoras", in: The Philosophical Review, 59 (1950) 31-57. Willy Theiler, Zur Geschichte der teleologischen Naturbetrachtung bis auf Aristoteles (de Gruyter, Berlin, 1965), pp. 1-54.

16. H. Diels, Die Fragmente der Vorsokratiker: Democritus: Fragment B 34. Compare Walther Kranz, Kosmos und Mensch in der Vorstellung frühen Griechentums (Nachdruck, Göttingen, 1938), pp. 150ff.

17. Compare W. K. C. Guthrie, A History of Greek Philosophy, vol. I, p. 208, note, 1.

18. See J. Kerschensteiner, Kosmos: Quellenkritische Untersuchungen zu den Vorsokratikern, p. 224. 
ory of mechanical causation. His alternative consists in accepting a stereometry (Tim. 35) and introducing an intelligent principle as the author of order. He retains both the tectonic notion of Anaximander and the ethicopolitical insights of the Pythagoreans. The latter position is evident in the assumption that alike kósmos both the soul and the state are artifacts. To the soul and the state is given an inner order, the world-order serves as its paradigm. Consequently, the triad of classes in the society corresponds to the triad of powers of the soul. In both cases paideia enhances the implementation of order. Plato thus transcends the material concept of order ${ }^{19}$.

The order in the world is, however, only a copy of the eternal order. This would mean that the Platonic concept of kósmos denotes a state in which the matter is subordinated to the form. In other words, Plato raises order to the realm of reason (Nomoi, X). According to this order any individual thing has a specific place allotted to it within the totality. And an ideal society is established when the society succeeds in converting itself into a mirror of nature by implementing the principles of kósmos in interhuman relationships. Plato would, therefore, assert that lawful order ${ }^{20}$ is ensured when laws are observed. The criterion with which to measure the order of law is reason. For it has constituted the kósmos by establishing a goal: the highest Idea. Wherever the human reason succeeds in discovering this goal, it has the reality in grip; as long as the human action is in consonance with this goal, it maintains and realizes the Good; in effect the will has surrendered itself to the highest Idea, Good. What the humans were to gain in liberty with this falling in order has been quite modest in the Platonic vision. For man exists for the world, not vice versa. In spite of the Aristotelian criticism and consequent additions the ancient concept of order would remain essentially this Platonic synthesis.

\section{2. The Concept of Order in the Middle Ages}

From its very beginning the Christian thought has esteemed and incorporated the Greek philosophy so much so that its Christianisation alters radically the concept of kósmos. W. Kranz observes rightly that kósmos in Augustinian sense means also order ${ }^{21}$. Augustine's concept of order, unlike

19. Compare Hugo Perls, Platon: sa conception du kosmos (Éditions de la maison française, New York, 1945), vol. 1, esp. pp. 33f. \& 262 f.

20. táxis kaí nómos. Compare Nomoi, 673 e; 780 d; \& 835 b.

21. »Kosmos heißt, so kann man sagen, Augustinisch auch Ordo«, W. Kranz, "Kosmos," in: Archiv für Begriffsgeschichte, $2 / 2$ (1957), p. 118. 
that of the Greek philosophers, is founded on the image of God reflected in the nature and thereby admits a triadic structure of the universe. To a certain extent the ancient philosophy attempted to decipher this structure with the concepts of logos, kósmos and taxis. It has thus served as precursor to the Christian thought. Augustine believes that the human beings, thanks to their intelligence would recognize the universal order and that this knowledge would enable them to raise their eyes towards God, the source of all truth and wisdom ${ }^{22}$. Distinguished by such a knowledge, man secures for him a place in the universe between God and the animal kingdom. In spite of later modifications and refinements by Bonaventure and Thomas Aquinas the Augustinian version remains the basic, medieval Christian concept of order ${ }^{23}$. Its strength lies in the ontological-philosophical interpretation, introducing God as the guarantor of ordo. I shall briefly discuss two points of this essentially metaphysical conception: the triadic notion of order and the question of evil.

Fundamental to the medieval Christian conception is its dumb acceptance of an order in the universe. The order is so evident and unquestionable that its rejection can challenge the integrity of human intelligence; ignorance of order results from human weakness. Order is beyond all genera, it is everyone's due and no existence can be thought of without or outside order ${ }^{24}$. This postulate that everything from its very first moment of existence is ordered, follows from the Christian doctrine of creation to which, according to the medieval thinkers, the biblical passage: omnia in mensura, numero et pondere disposuisti ${ }^{25}$ alleges. Consequently the source of all order is God Himself. Admitting that measure, number and weight are three metaphysical principles of being, and refer to the emergence, form and finality of an existence, their unity would signify the fullness of being in any existence. Mensura, numerus and pondus are thus aggregates of order; in their elaboration consists the medieval Christian metaphysics of order.

The expression mensura or measure specifies any existence with regard to its emergence in a triple perspective of modus, prioritas and gradus. Whereas

22. Augustine, De ordine II, 19, 51.

23. »Fast alles, was Thomas über den Ordobegriff und seine Beziehung zu anderen Begriffen, ... ausführt, ist im wesentlichen bereits bei Augustine vorgebildet« Hans Meyer, Thomas von Aquin. Sein system und seine geistesgeschichtliche Stellung (Paderbon, $\left.{ }^{2} 1961\right)$, pp. 371-372.

24. Compare Augustine, De ordine, I, 1, 2f.; Hermann Krings, Ordo. Philosophisch-historische Grundlegung einer abendländischen Idee (Felix Meiner Verlag, Hamburg, ${ }^{2} 1982$ ), p. $27 \mathrm{f}$.

25. Sapientia 11, 20: "you have disposed all things by measure and number and weight «. For further quotations and references, see P. G. Pandimakil, Das Ordnungsdenken bei G. B. Vico, pp. 37f., esp. note 131. 
mode refers to the particular grounds or requirements of any being's emergence and priority its temporal dimension, grade indicates its position in the ladder of beings. All these three moments of measure together signify the intensity of being, on which criterion the hierarchy of all existence is determined. Further, these integral moments of measure account for the singularity, temporality and worth of each and every existence without resorting to the notion of finality. In spite of the fact that the Augustinian definition of order as »parium dispariumque rerum sua cuique tribuens loca dispositio 26 incorporates fully the concept of mensura, the emphasis both in Augustine and in the medieval thought lies on the sphere of transcendence. For mensura alone does not determine the rank of existence, but in association with numerus ${ }^{27}$. The intensity of being in an existence is hence inalienably linked with its individuality.

In describing an existence as ordered by numerus, the medieval thought assigns it a three-polar identity: by distinction, of species and by pulchritude. Since numerus and numerositas ${ }^{28}$ express the entirety of being fixed by mensura, every substance can be conceived as a unity, an individuum. Individuality or unity is always vindicated by characteristics through which an existence distinguishes itself from another. There is no.identity without distinction; and distinction enables order. For it starts with the simple, formal assertion: unum non est alterum ${ }^{29}$. But what is it that distinguishes a thing from another? According to Augustine it is species propria ${ }^{30}$, meaning both class and form. How the complex term numerus indicating simultaneously distinction, class and form is applicable to a substance is analogously explained: Just as the addition or substraction of unity alters the class of a number, so does the difference in form denote the grade of perfectio (i. e. similitude to God) in an existence. Distinction in form or class means limitedness in perfection. In other words, number expresses metaphysically the specificity of an existence in reference to its creaturely perfection; form and class partially specify the substance respectively in reference to itself and to other existence. Pulchri-

26. De civitate dei, XIX, 13 .

27. Compare Josef Rief, Der Ordobegriff des jungen Augustinus (F. Schöningh, Paderborn, 1962), pp. 216ff.

28. In the medieval philosophy, numerus is understood both as numerus transcendens and as prima mensura quantitatis. Numerositas, the state of being numbered, signifies transcendental unity and plurality of substances. It is constituted of two notions: that an existence can be both internally and externally determined; it is esse indivisum and esse distinctum. Compare Thomas Aquinas, Summa Theologiae I, q. 11, a. $1 \& 2$.

29. Th. Aquinas, De potentia IX, 7. Or, according to Summa contra gentiles I, 71: "distincta enim sunt quorum unum non est aliud «

30. De vera religione 7, 13; see also: De genesis ad litteram IV, 3 . 
tude, on the other hand, denotes the appearance of an existence in actual order; it is also species meaning both internal and external order of a substance. Representing beauty as the living aspect of being to be experienced or as the object of metaphysical vision the medieval thought emphasizes the unity realized in a substance and the specificity expressible through number. However, it is mensura which formally enables the order according to numerus.

Pondus as the third integral principle of order postulates the finality of all existence, expressible in three moments: inclinatio, relatio and finis. Inclinatio signifies the dynamic moment or natural tendency intrinsic in every existence to become what it is supposed to be. This constitutes the basis of relatio which is ordering an existence in respect to another. Relatio in this sense is materially, not formally, identical with the concept of ordo. For we speak of relatio when two distinct or opposed substances somehow or other establish a relative unity. The spectrum is widened in the case of ordo to postulate a relatio between immanence and transcendence, which in fact is inaccessible to human intelligence. However, this comparison between relatio and ordo serves to determine the kind of being attributable to ordo. It is precisely what Aristotle speaks of as prós $t i$ and detects in the image of a marching army: ordered interrelationship makes an army what it is ${ }^{31}$. Order is thus founded on things: it is a being-in-between. Consequently, relatio assures that order cannot exist for itself, it is a medium of all being: all existence is end-oriented. Finis, the end, denotes the goal towards which all move, namely the good. The good is postulated both as finis proximus and finis ultimus, the latter attainable only through the former. A clear picture of this conception is given in the figure of an army general ${ }^{32}$, who personifies the finis ultimus, which however will be realized only as a result of the fulfilment of proximate ends. The core of finis consists thus in accomplishment: each existence in its own manner attaining the goal set to it.

In conceiving mensura, numerus and pondus as principles of order the medieval Christian thought offers, as mentioned early, a metaphysical explanation of the image of God in the universe. They correspond to the divine attributes of potentia, sapientia and bonitas -might, wisdom and excellencethrough which God's presence in the universe is experienced ${ }^{33}$. Besides, the

31. Catagoriae 7 (6a 36f.); Metafisica V, 15 (1021 a 26-29); cf. Th. Aquinas, Summa contra gentiles, III, 64; Summa theologiae, I, q. 15, a.2.

32. Compare H. Krings, Ordo, p. 70.

33. Compare Albertus Magnus, Summa Theologiae I, tract. I, q. 3, mb. 3, a. 4, sol. See also H. Krings, Ordo, p. 87. 
hierarchically -i. e., according to pefectio - ordered picture of all created existence which the metaphysical vision guarantees in terms of the triad: mensura, numerus and pondus should be a demonstration of divine perfection. Man's place in the universe is thus given and determined by an order whose author is God Himself34. Is man, then, responsible for the evil in the universe? To what extent is he free in this divinely ordered universe? The Augustinian discussion of evil confronts primarily these issues.

In his analysis of the problematics of evil Augustine employs a strategy which even today commands admiration ${ }^{35}$. He begins by denouncing any admission of malum metaphysicum, for it either leads to Manichaeism or implicates God as the author of evil. No realist can, of course, disagree that evil exists. But what is evil? For Augustine it is perversio, corruptio, confusio, defectio, etc. all of which do not indicate a being but the absence of what an existence ought to possess. Evil is, to employ the expression of Thomas Aquinas, »defectus boni quod natum est et debet haberi«36. Both malum morale and malum physicum conform to this affirmation, even though it is more adequate to speak of perversio in the former and corruptio in the latter case. On this postulate, the existence of evil cannot contradict the concept of order.

But why there is evil? Augustine's answer is theological-philosophical. From faith one knows that there exists nothing beside or beyond order. From a total perspective order encompasses evil and the presence of evil should serve a better life. But how? Evil might be an appeal to reason to conscientise man of his true nature. Since he is called to happiness through order, the misery suffered through evil might awake in him the awareness of his proper goal. Malum fulfils thereby a curative-pedagogical function in the Augustinian vision ${ }^{37}$. Evil is meaningful as far as it serves the self-assertion of man by reminding him of his status in the imminent context of punishment. Providence does not defy human liberty, it does not correct it externally, but is present immanently with it 38 .

34. Compare Th. Aquinas, Summa theologiae I, q. 104, a. 2, ad 1; cf. Bonaventure, Commentarius in I. Librum Sententiarum, dist. 44, a. 1, q. 3 concl.

35. Compare P. G. Pandimakil, Das Ordnungsdenken bei G. B. Vico, pp. 53f. For a recent brief discussion on this issue, see Argimiro Turrado, "El problema del mal y la responsabilidad de las personas especialmente en la «Ciudad de Dios» de San Agustín", in: Revista Agustiniana 36 (1995) 733-789.

36. Th. Aquinas, Summa theologiae I, q. 49, a. 1, resp.

37. Compare J. Rief, Der Ordobegiff des Jungen Augustinus, pp. $252 \mathrm{f}$. p. 117.

38. Compare Kurt Flasch, Augustin. Einführung in sein Denken (Reclam, Stuttgart 1980), 
The import of the Augustinian argument consists in its capacity to reshape the philosophy of order. With his outright rejection of malum metaphysicum Augustine opens up a new vision: evil can be conceived only in terms of relation. What can be judged as evil, should emerge from the individuality of existence. Our attention should move from being in general to concrete existence. This shift in perspective results from the conviction that the causes of (human) evil and misery ought not be sought beyond human beings. In other words, the fact of malum physicum is explained through the presence of malum morale. Or better, because humans are evil, there is evil in the world. Augustine thereby enables man to be the author of his actions -thanks to a creative will- without depriving the divine order of its might. Here is then the Augustinian strategy to solve the question of evil: an anthropocentric shift in a theocentric universe. It will be the Renaissance philosophy to capture and exploit this Augustinian vision in a manner Augustine himself would not have ever envisaged.

\section{I.3. The Renaissance philosophy of order}

True to its name the Renaissance postulates the self-assertion of man by resuscitating the classic Greek thought ${ }^{39}$. Representative figures of this period who might help enlighten Vico's anthropology are Marsilio Ficino, Giovanni Pico della Mirandola and Giordano Bruno. While the Renaissance Platonist philosophy of Ficino and Pico illustrates the continuity and advance of the concept of order since the Middle Ages, Bruno's thought underlines an issue still discussed and disputed in our own days, namely the question of subjectivity. Ficino, Pico and Bruno shall thus enable us to discover the metaphysical background and epistemological relevance of Vico's thought. On both these branches is founded the anthropology of the New Science, the central issue of Vico's philosophy of order. It is hence important to ask how Ficino reformulates the self-assertion of man from a Platonic perspective.

In his Theologia Platonica (1469f.) Ficino's main concern is to prove the immortality of the soul. He attempts to fulfil this task by conceiving the universe as an ordered unity, in a manner alike but also different from what the ancient and medieval philosophers thought 40 . His strategy consists in a

39. For a brief introduction, see Brian P. Copenhaver \& Charles B. Schmitt, Renaissance Philosophy (A History of Western Philosophy: 3, Oxford University Press, Oxford/NY, 1992), esp. ch. 1: "The Historical Context of Renaissance Philosophy". 1964).

40. Compare Paul Oskar Kristeller, The Philosophy of Marsilio Ficino (Gloucester, Mass. 
Christian interpretation of Plotinus' structure of being. According to Plotinus six analogous domains - én, nous, psyché, aisthesis, physis and soma - constitute the being, which in Ficino's conception become five - God, angel, soul, quality and matter - indicating the distinct grades according to the intensity of being. The basic structure proposed and the analogical arguments employed to substantiate it require that the characteristics of the lower grades are found in the higher too. A relation of causality exists between the higher and the lower grades: it explains both the multiplicity and motion in the universe. To God, the highest being, are attributed unity and rest. Unique in this conception is the affirmation that no difference can be thought of without a hierarchy. Order must be therefore hierarchical. And hierarchy assigns the soul a singular place: it is the connecting link between the spiritual and material realms of the universe.

With the assumption that the soul acts as the connecting link in the universal hierarchical structure Ficino wants to emphasise the correlative aspect of being. He therefore postulates a threefold relationship - of symbolism, continuity and affinity - between the different domains. The main symbolism employed is that of light, God, for example, as the sun vivifying the universe. A relationship in the Platonic pattern of original to copy signifies for Ficino ontological and symbolic hierarchy: the rank of an existence is determined not exclusively by its participation in the ultimate being but also by its capacity to manifest it. In the order of their ontological proximity to the ultimate being things in the world can be classified as imagines, vestigia and umbrae Dei. But in the task of leading man, for example, to God any of this would do: the whole world bears His hallmark ${ }^{41}$. It is an open book for man to read from.

In Ficino's hierarchical conception of the universal order there is a seamless continuity guaranteed through the affinity of the middle region to both the lower and the upper ones. Moreover he considers this affinity as constitutive of any intermediary (medium) and hence universally applicable. To carry out its function an intermediary need participate equally in the characteristics of the extremes between which it mediates. However, regardless of the nature of the extremes the intermediary is able to function properly as long as it is in concordance with them. According to Ficino such an intermediary is the soul, which as the formal principle links the extreme domains of being and constitutes unity in the universe. The symmetry of world order has thus the

41. Compare Ernst Cassirer, "Ficino's place in intellectual history", in: A Journal of the History of Ideas 6 (1945) 483-501; esp. pp. 494-496. 
soul in its centre. However, the world order is not static, but dynamic; and this dynamism is guaranteed through the relation of affinity.

Ficino illustrates the concept of affinity by applying it to the domains both of thought and of love. Thought is an internal activity of a thinking being which according to its nature should be conceived as immaterial: it is an activity of the mind or intellect. Both the thinking subject and the object of thought belong to the material world. In order that knowledge is possible two conditions should be satisfied. First, there must exist a subject-object correlation based on some similarity: "non est putandum ... operationem versari circa objectum aliquod nisi simile, commodum et conveniens «42. Second, there should exist a concordance in the level of contents: aequatio mentis cum rebus, as the scholastics would put it. Ficino understands this aequatio as an active operation which consists in the intellect becoming really united with the object of thought. Consequently the object is enabled to participate in the being of the intellect and thereby raised to the level of immateriality. Thus a formal subject-object concordance is given between the soul and the object apprehended by it. Eventually in the act of thinking the soul overcomes the bridge between the intelligible and the material worlds. Similarly, but more extensively applicable is the concept of affinity in the domain of love. Ficino's interest consists in proving that the soul due to its central position possesses correlations with the higher, lower and like beings, and these relations based on similitude are products of affinity or love, for amorem procreat similitu$d o^{43}$. Affinity or love thus confirms the metaphysical status of soul: it is nodus perpetuus et copula mundi or vinculum universi.

With his conception of order Ficino intends to prove, as mentioned early, the immortality of the soul, and it is in this context the question of its nature becomes extremely crucial. The soul as subject of thought and love is immaterial, and as vinculum universi is inevitable to maintain the ordo universi. Besides the inner experience testifies to its immateriality: Sic enim experientia ipsa constabit primo quidem qualis ist purus animus, id est ratio secum ipsa vivens seque circa ipsum veritatis lumen avide versans ${ }^{44}$. However, it's important to note that Ficino overlooks the functional difference within the soul and identifies it with the human being. And since the beatific vision constitutes the final end of being human, the denial of immortality would impede man from realizing his end. Moreover such a measure would dehumanize him.

42. Marsilii Ficini Opera Omnia (2 vols., repr., Turin 1959), p. 238.

43. Ficino, Opera omnia, p. 1328.

44. Ficino, Opera omnia, p. 159. 
Consequently the soul cannot but be immortal according to its nature; consonant to this nature is also its structure.

The soul has a tripartite structure consisting of mens, ratio and idolum. While mens and ratio, respectively higher and middle parts, are faculties of knowledge, idolum, the lower part, is constituted of three powers: phantasy, sensation and nutrition. Briefly, Ficino postulates mens as the pure thinking faculty for contemplation, idolum as the centre of empirical vital functions and ratio as the most important element, constituent of freedom and seat of consciousness. The importance attributed to ratio is based also on its specific function: "ratiocinatio, id est, a principiis ad conclusiones, a causis ad effectus artificiosa discursio ${ }^{45}$. Both an ascent from the material to the intellectual and a descent from the intellectual to the material spheres are meant under discursive thought; it is hence cyclical and is accomplished thanks to phantasy. For phantasy alone enables the knowledge of individuum. Ratiocinatio constitutes thus the centre of ratio; if ratio is the distinctive mark of human beings ratiocinatio is its core; herein lies the specificity of man.

In establishing man's specificity for the possession of ratio Ficino defines man from the standpoint of anima rationalis, which can both ascend and descend on the ladder of being. The soul, consequently the human being, stands on the border of materiality and immateriality building thereby a sort of link between the two halves of being. It therefore possesses a natural tendency towards body and an equally natural one towards the godhead. Pleasure and contemplation follow from this Janian nature of soul. How the medieval concept of order is transformed, becomes evident from this description of man's place in the universe: although order continues to be an expression of substance metaphysics and determines man to a great extent, his potential of selfdetermination is now discovered and openly acknowledged. There is a clear tendency towards defining man from a functional perspective. Pico can build up on this conception.

In his Oration on the Dignity of man Pico in fact exploits and transcends the metaphysical dimension added by Ficino to man's cosmological centrality. Unlike for Ficino the expression of human freedom consists not merely in a contemplative ascent towards the godhead, but more in discovering and making use of the creative potential available to man. Therefore, in Pico's account of the Genesis God would instruct Adam to elect his place and to be what he wants to be. If he is set in the centre of the world, it is not for that he

45. M. Ficino, The Philebus Commentary. (A critical edition and translation, by M. J. B. Allen, University of California Press, 1975), p. 317. 
stays there, but to look around and transcend the centrality ${ }^{46}$. To the genesis of humanity or civilization is essential the power of productivity. Both ontological and moral freedom are thus assigned to man. As a result the scholastic principle of operari sequitur esse is reversed: actions now constitute the essence. Further, as Cassirer rightly points out: »What he [Pico] sets up as the distinctive privilege of man is the almost unlimited power of self-transformation «47. Accordingly the Oration requires man to lead the intellectual life of the Cherubim, and not to be content with a single set of doctrines. He has to select the best from diverse and often contradictory teachings to lead a life worthy of human vocation. Pico's eclecticism and concordism are thus the methodological aspects of his concept of freedom. This is a long way from Ficino who contents with discovering Egyptian wisdom and Christian theology in Platonism. However both Ficino and Pico attempt to preserve the scholastic ontology despite presenting it in new cosmological perspectives. More radical is the approach of Giordano Bruno.

It is from an epistemological perspective that the contribution of Bruno contrasts with that of Ficino and results especially useful in understanding Vico. In discussing the concept of affinity we have seen how Ficino interprets the scholastic aequatio by assuming that the soul-intellect thanks to its privileged position in the hierarchy of beings becomes the thing in the act of apprehending it. Bruno employs this notion in interpreting the myth of Actaeon and thereby postulates a theory of the self-consciousness of man ${ }^{48}$. The epistemological interpretation of the myth concentrates on three moments: Actaeon-the hunter, Actaeon-the deer, and Actaeon-the prey. Motivated through the will, the intellect hunts for divine wisdom; in perceiving the bathing Artemis the intellect catches a glimpse of the divine beauty. And the mere perception of the naked beauty transforms the hunter into the hunted:

46. »Nec certam sedem, nec propriam faciem, nec munus ullum peculiare tibi dedimus, o Adam, ut quam sedem, quam faciem, quae munera tute optaveris, ea, pro voto pro tua sententia, habeas et possideas. Definita ceteris natura intra praescriptas a nobis leges coerceturr. $\mathrm{Tu}$, nullis angustiis coercitus, pro tuo arbitrio, in cuius manu te posui, tibi illam praefinies. Medium te mundi posui, ut circumspiceres inde commodius quicquid est in mundo.« G. Pico della Mirandola, De hominis dignitate (Latin/German, trans. by N. Baumgarten, F. Meiner Hamburg 1990), pp. 4\&6.

47. Ernst Cassirer, "Giovanni Pico della Mirandola", in: A Journal of the History of Ideas, 3 (1942), 123-144 \& 319-346; here, p. 331.

48. Compare Giordano Bruno, Des Fureurs Hérö̈ques (trans. and ed. by Paul-Henri Michel, Paris 1954), pp. 204-209. Werner Beierwaltes, "Actaeon. Zu einem mythologischen Symbol Giordano Brunos," Zeitschrift für philosophische Forschung 32 (1978) 345-354. 
subject becomes object. In this new state Actaeon-the deer (i.e., will) pursues unknown paths into denser thickets, into the region of things beyond comprehension. Actaeon's state has been that of a common, ordinary man; he now becomes rare and heroic, but only to be chased, rent and devoured by his own dogs (i.e., senses). The intellect in pursuit of knowledge becomes the best booty: the privileged object of consumption. From now on Actaeon begins to live intellectually, to live the life of gods.

Among the three moments mentioned above namely perception, transformation and consumption the second is central ${ }^{49}$. For the transformation which despite its character of crossing the frontiers is positively valued; it enables a qualitatively new intellectual state: vivere intelletualmente, vive vita de dei. It, however, requires the hunter to be devoured by his own dogs. Bruno thereby expresses metaphorically that the transformation signifies a transition of action from intellect to will. For, whereas the intellect perceives the thing according to its laws, the will conforms itself to the laws of the thing. Primacy of will is therefore necessary to safeguard the objective reality, to guarantee the objectivity of knowledge. Not a Platonic ascendency, but a separation of the opposites constitutes the structure of human cognition. Knowledge, of course, does violence both to subject and object: every acquisition of knowledge involves inevitably some loss.

Thus the human self-consciousness emerges according to Bruno thanks to an internal tension within the human cognitive process, which he is unable to control. It is the intensity of the will to know, to live, that makes the core of subjectivity. We might call it intensive thought 50 . Proposing intensive thought instead of anima rationalis as the distinctive mark of man Bruno calls for a life-style that keeps the passions under aesthetic laws. A life fashioned after a sense-based qualitative thought is neither utopian nor resigned; it is a permanent effort to awake and maintain a consciousness of the limits of thought and life, and at times to be ready to challenge these very same limits.

If freedom, immortality and God constitute the great themes of the Renaissance philosophy, in its centre is to be set the question of subjectivity. For it is the definition of man starting with an epistemological perspective that determines his place in the universe and specifies his self-assertion. The

49. Compare Ferdinand Fellmann, "Giordano Bruno und die Anfänge des modernen Denkens" (in: Die Pluralität der Welten. Aspekte der Renaissance in der Romania, ed. by W.D. Stempel \& K. Stierle, Fink, München, 1987), pp. 449-488.

50. See Ferdinand Fellmann, "Heroische Leidenschaften und die Entstehung der philosophischen Anthropologie" (introduction to G. Bruno, Von den heroischen Leidenschaften, trans. \& ed. by C. Bacmeister, F. Meiner, Hamburg, 1989), pp. vii-xl. 
Renaissance thinkers judge correctly the rigours of medieval order, they do well appreciate the divine wisdom but do not resign to the limits set by it to humanity. Their quest to widen the frontiers of humanity by resorting to classic Greek thought results often in transforming and transcending the medieval conception of natural order. A necessary consequence of this re-discovery of man which Renaissance embarks upon is to make man conscious of his own limits. And to be conscious of the limits, according to Hegel, amounts to overcoming them. But for this it is necessary to make a full turn towards anthropology from cosmology what Vico undertakes in his New Science. In order to define man and to describe his self-assertion from a philosophical-anthropological perspective one has to begin, according to Vico, by resorting to what is utmost true and essential to human nature, namely la vera civile natura dell uomo. He intends thereby to introduce a new method and a new terrain of study, both of which would reformulate and advance the philosophy of order up to the modern times.

\section{VICO'S INNOVATION TO THE PHILOSOPHY OF ORDER}

It must have become evident from the preceding discussion that both the ancient and medieval thinkers assume the existence of an order, and consequently man is assigned a place within an already given order. The principle which sustains this conception is teleology; its unacceptableness especially due to the devaluation of the lower grades against the higher has obliged the Renaissance thinkers to offer a new interpretation of the philosophy of order. Impetus for a critique of teleology has been already rendered in the nominalist reflection on human condition. For the admission of God's omnipotence would, according to this view, contradict the Nicene Creed: an almighty God could not have created the world propter nos homines but propter se ipsum ${ }^{51}$. The Ficinian metaphysics of order is to a certain extent a reaction to this voluntaristic conception of God. In his hierarchical system the world cannot subsist without man, even if it were not made for his sake. Man's real excellence consists in transcending the world in a Platonic ascent. Human soul is

51. See Hans Blumenberg, Die Legitimität der Neuzeit (Suhrkamp, Frankfurt a. M., 21988), pp. 197; 214-218. Paul Vignaux, "Nominalisme", in: Dictionnaire de Théologie Catholique, vol. 11 (Librairie Letouzey et Ané, Paris 1931), 864-904. 
a divine substance and one should view the soul of things with the eyes of the soul. Real philosophy consists in apprehending the mystery of the universe thanks to a transcendental perspective of the reality. In the Ficinian hierarchy man has thus a fixed, but important place, limited freedom, definite and atemporal end. The human soul is capable of ascending to the divine realm and of capturing the essence of things. From this functionally strategic position emerges the fundamental human excellence. However, all human action is dependent on the effectiveness of a transhuman will. It is above all to this dependency of man on the divine will that Vico reacts with his own version of order.

If human action is independent of transhuman elements, it is necessary to explain what causes or motivates action in man; who or what co-ordinates the human actions so that they do not mutually annihilate; how can one substantiate the diversity in human thought and action, etc. In short, to make man the author of his actions requires a radical reinterpretation of the hitherto conception of order. This is precisely what Vico undertakes in the New Science: an immanent and autopoietic reconstruction of human thought and action from the very first moments of their emergence in humanity. However, Vico's line of argument does not break away completely from the traditional concept of order, it rather builds up on the past.

Vico's concept of order extends through three spheres: metaphysical, epistemological and anthropological, of which the last proves to be the most original and hence shall occupy the main part of our discussion. Whereas from a metaphysical perspective $o r d o$ represents the fundament of every creaturely existence, from an epistemological view it guarantees and determines human knowledge. Every form of existence and every branch of knowledge can be traced back to the eternal and unchangeable order. This order is manifested in the workings of divine wisdom, and hence the New Science can rightly claim to be a rational political theology of divine providence52. Vico's metaphysics is in other words presented in theological terminology.

Reflection on the workings of divine providence in the universe allows Vico to describe the nature of human dependency on God. However the question is inalienably linked to human cognition and action, and hence Vico founds both his epistemology and anthropology on the metaphysical conception of order. From an anthropological perspective ordo allows a symbolicpragmatic interpretation of human beginnings and development. The mechanisms of the beginnings undergo modification and continue to work in furt- 
her stages of civilization; for they are inevitable in preserving the human society. Hence order cannot be dispensed with at any stage of human civilization. But what kind of order? An unchangeable and eternal order of things brought forth by changeable and contingent beings. That such an order underlies the reality makes a central issue in Vico's critique of Descartes. I shall discuss this point in the context of Vico's functional metaphysics.

\section{II.1. Order as a metaphysical-epistemological concept}

Vico's metaphysics of order is anchored in his philosophy of mind which finds expression primarily in the Liber metaphysicus and in the first part of $D e$ universi iuris uno principio et fine uno. Whereas in the former work Vico in response to Descartes formulates a criterion of truth on the basis of the scholastic thesis of the interchangeability of transcendentalia ${ }^{53}$, in the latter he postulates that the principles of human cognition and action are to be found in God, the infinite mind. Vico's famous verum-factum axiom proposed in the metaphysical book is extended in his treatise on Law to include a partial convertibility between verum and certum. Both the metaphysical-methodological critique of Descartes and the exposition of his functional metaphysics in contrast to the traditional substance metaphysics are brought under a single concept of truth which one obtains by »conforming the mind to the order of things $\ll 54$.

Vico's critique of Descartes is mainly directed to the latter's postulates on truth. According to Vico the Cartesian evidence of clarity and distinctiveness attributed to cogito, ergo sum cannot claim neither the status of metaphysical first truth nor that of scientific, experimental truth. Vico is of opinion that apart from the different kinds of truths which we produce speculatively or experimentally, it is necessary to postulate an absolute and eternal truth that can function as measure of all factuality. He therefore does not propose a metaphysics of the most clear and distinct, but that of a truth to be clarified

53. The scholastic statement ens, verum, bonum et pulchrum convertuntur forms the basis of the so-called Vico-axiom: verum et factum convertuntur, which is introduced as the criterion of science. See Liber metaphysicus (De antiquissima Italorum sapientia. Risposte. LatinItalian-German, transl. \& ed. by S. Otto \& H. Viechtbauer, Munich 1979), ch. 1, section 2.

54. Opere di G. B. Vico (ed. F. Nicolini \& G. Gentile, Bari 1911-1941), vol. 2/1, p. 35. See also for more references P. G. Pandimakil, Das Ordnungsdenken bei Giambattista Vico, pp. 102-152. The present exposition follows the line of thought in: Stephan Otto, Giambattista Vico: Grundzüge seiner Philosophie (Kohlhammer, Stuttgart 1989), esp. pp. $62 \mathrm{ff}$. 
gradually. His is a metaphysics of human mind which apprehends the truth out of the difference between the measurable and factually produced truth. The thesis of convertibility or of mutual conditionality between truth (verum) and fact (factum) proposed in Liber metaphysicus, would mean: such an absolute claim of truth as Descartes' for his cogito will be unacceptable even in scientific endeavours, for the analytic geometrical propositions lack the factual dimension. In contrast to the Cartesian evidence which amounts to a mere consciousness (conscientia) and hence falls short of science (scientia) Vico proposes an action-based certainty: veri criterium est idipsum fecisse ${ }^{55}$. With the affirmation that the criterion of truth is to have produced it Vico opts for a metaphysics based on the productivity/creativity of mind as in Geometry. Both the geometrical figures and mathematical numbers are mental products whose truth is fully accessible and demonstrable to mind.

However, a problem surfaces by accepting the criterion of truth proposed by Vico: if geometrical or mathematical constructs are true because they are mental products what reality can they claim for themselves? Are they not mere ideal things? Vico confronts this problem in a twofold manner. First of all he compares the clarity of metaphysical truth to light, which we apprehend only on the background of shadows. It is through the medium of truth made by man and as a difference to the metaphysical truth that we shall approach the eternal truth. In other words, notwithstanding man has not made metaphysical or eternal truth, it is accessible to him for the simple fact that it also is made. If thinking is creative action, what is brought forth in thought and insight should be something made; and since God is the first maker he, not cogito, becomes the first truth of all created things. This, in fact, does not offer much reality to what is made by humans, but distinguishes between natural and mathematical knowledge. The latter possesses exactness because man knows that he has produced the forms and numbers. A full identity between knowing and making exists only in the case of God. It is hence useless to employ a metaphysics of being or substance in explaining the process of human knowledge; it should be sought elsewhere. Consequently Vico distinguishes between the mode of production in reference to God and to man. Whereas the former generates, the latter makes: divine truth is genitum, human truth is factum. This amounts to employing a functional metaphysics alike Ficino's and unlike Descartes'. It differentiates between the mode of emergence of metaphysical and factually made truth; between the modalities of philosophical and scientific knowledge. It is not the being as such that cons- 
titutes the object of knowledge, but the manner how things come into being. From this explanation it is possible to understand the gist of Vico's criticism of Descartes. He attacks both the static metaphysics of the clear and distinctive idea and the scientific method of deductive analysis. In fact Descartes offers only a mechanical explanation of extension which amounts to a quantitative change in bodies. In contrast Vico proposes a qualitative concept of motion and change in nature which should further account for the reality of man-made truth. The theory of metaphysical points and conatus addresses this problem.

In explaining linear motion and consequently all bodily extension, the seventeenth century thinkers postulate an impetus or force distinguished from the factual movement of bodies as responsible for all motion. Vico's acceptance and elaboration of this theory makes sense in the context of his functional metaphysics. Alike a mathematician Vico assumes limits of human knowledge which should not be transcended but acknowledged to mark the frontiers of thought ${ }^{56}$. From a functional metaphysical perspective the Cartesian apprehension does not go beyond the clarity and quantity of individual natural things, and hence is content with the principles of things. Vico on the other hand attempts to capture the principles of extension itself, the dynamic form with which things come into existence ${ }^{57}$. These principles are for Vico limit-concepts, since they distinguish the three dimensional substance from the metaphysical realm. Such are then the metaphysical points whose property is conatus 58 .

What does all this mean to motion and quantity? Both the minimal extension and the least movement should not be explained mechanically, but conceived in contrast to nothing: point and impulse as principles of extension and movement respectively are infinite; both are limits of empirically measurable categories. This amounts to perceiving finite things in an infinite perspective. However, from a metaphysical point of view they are not simply limit-ideas but also productive principles or creative forces. Vico explains this point by referring to the infinite divisibility of a grain of sand. What this statement expresses is not a truth accessible by empirical division; it refers to a definite force in natural things which cannot be defined by natural sciences: there is a domain of truth in natural things accessible only to metaphysics. Vico presents thus his functional metaphysics as a guarantee to science. So it makes

56. Compare Liber metaphysicus, pp. 86/87.

57. See Liber metaphysicus, pp. 164/165; 58/59; \& 40/41.

58. Liber metaphysicus, pp. 82/83. 
sense to speak of nature as movement, whose ultimate ground is God: Natura est motus; huius motus indefinita movendi virtus conatus; quam excitat infinita mens in se quieta, Deus. Naturae opera motu perficiuntur, conatus incipiunt fieri; ut rerum geneses motum, motus conatum, conatus Deum sequatur 59 .

Admitting that God is the ultimate ground of extension and movement Vico not only differentiates the created substances from the divine substance but, like Plato, also proposes geometry as a model of thought. The metaphysical point as indivisible principle illustrates the pattern of geometrical thought which consists essentially in projecting and discovering. Although Vico's argument resembles an ascent from representation to representability, his pointe is to prove the possibility of postulating an infinite indivisibility, for example, as the ground of Euclid's definition of a point (which does not have parts). The admission that metaphysical point and conatus are principles of extension and movement enables one to transcend these and to arrive at an idea of eternal, unchanging truth, which is identical to God. In fact, Vico projects his metaphysical notions on the theological conception of God - an attempt he considers helpful to conform philosophy to religion. These aspects of Vico's philosophy seem meaningful in affirming the real limits and possibilities of human knowledge; man who has not made the world has to understand it thanks to a metaphysics of mind, by projecting, deciphering and discovering the functional principles of the natural world. In other words, only in reference to the primary truth, God, all other truths and man himself can be adequately explained. And one arrives at the primary truth thanks to an eternal and unchangeable order.

Vico's axiom: verum et factum convertuntur has also another dimension which postulates a partial convertibility between verum and certum. Vico employs the concept of certum in the context of natural law and history. Its metaphysical relevance consists in linking positive law to the idea of right: i.e., facticity to truth and thereby to bring out the portent of historical certainty. In other words, he attempts to capture the positive law of different peoples as manifestations of an eternal, true right. Vico therefore speaks of ius naturale gentium, rather than of ius naturale. The expression ius naturale gentium refers to a social order or common nature of peoples. How the common nature of peoples constitutes itself, how historically consciousness of right emerges and develops in the world are questions to be answered in reference to verum and certum. From a metaphysical perspective Vico offers the principles of truth which exist beyond the order of natural things, but still govern them.

59. Liber metaphysicus, p. 90. 
Vico's point is made clear by explaining the relationship between truth, certainty and facticity applied to law. Jurisprudence is based on intellect and authority; it is exercised correctly if it conforms to the facts. The intelligence required for a just execution of law is prudence or insight into the truth of things, and the authority referred to reflects the will of the law-giver, introducing a historical component. Since the execution of law consists in realizing the right both will and intellect have to conform to the facts. This amounts to attributing to the principles of jurisprudence a methodological profile: the relation between intellect and authority is parallel on the one hand to philosophy and philology (i.e. all human sciences), and on the other to truth and certainty. Between truth and certainty, there exists no contradiction but complementarity: the latter is part of the former. An exclusive dependence on certainty guaranteed by authority would make one a thorough pragmatist, and a similar reliance on truth supported by intelligence a philosopher. Both truth and certainty are interlinked through the ingenious method of conforming them to the factual reality. Facts can change and so the mind of the lawgiver, namely authority, but the constitutive principle of conforming the right to the facts remains the same: Mens legis est voluntas legislatoris: ratio legis est conformatio legis ad factum. Facta mutari possunt, et mens legis, seu voluntas legislatoris mutatur: conformatio autem legis ad factum mutari non potest, unde nunquam ratio legis mutatur. ... Mens legis spectat ad utilitatem, qua variante, variatur: ratio legis, cum sit ad factum conformatio, spectat ad honestatem, quae aeterna est ${ }^{60}$. Thus, it is the constitutive principle of conforming true and certain right to facts that remains constant, and consequently the structural net of truth and certainty also remain invariable. Verum, certum and the ingenious method of conforming these to the facts are the structural moments which confer constancy to the transcendental sense of right and law. In fact, Vico here reflects on the possibility of asserting justice as the fundamental condition both in finding truth and in the execution of law. His pointe is again primarily anti-Cartesian: the discarded moment of historical certainty in Descartes reappears now in a context of transcendental conditionality where from links both to the ideal and historical/positive levels can be established. Further, this theory of jurisprudence fits well within the philosophy of mind.

The human mind, in its structure triadic, is a mirror of the divine; its fundamental powers consist of nosse, velle and posse. Vico attempts to found the

60. Opere di G. B. Vico, vol. 2/1, p. 82 . 
knowledge of truth, the expression of authority and the ingenious method of conforming the true and certain to facts on the three elementary mental powers. Since he is also concerned with tracing the principles of all sciences to mind, nosse, velle and posse are considered simultaneously as principles of mind and of jurisprudence. And jurisprudence exemplifies all other disciplines: all science seeks truth, works with certainty and must be conformable to facts. That means also that all science can be traced back in its triadic form to the mind, the transcendental subject. It is for Vico the eternal order, infinite mind or God: idea ordini aeterni est idea mentis infinitae. Mens infinita Deus est: igitur idea ordinis aeterni haec tria nobis una opera demonstrat: et Deum esse, et mentem unam infinitam esse, et auctorem nobis aeternorum verorum esse $e^{61}$.

In this metaphysics of mind the idea of God functions as a limit-concept: God is infinite. The thinking, knowing and willing human subject is a finite mind tending towards infinity. Whence this human strife to infinity? Occasioned by conatus, understood now as vis veri. Besides being the motive force in nature the concept of conatus serves also to amplify the metaphysics of mind. It is for Vico the force which enables the weak to fight against the corrupt nature. Reinterpreting the theological concept of the tripartite divine image in man Vico makes the vis veri to engender scientia, ars and sapientia62. He thereby reinstates all the humanistic disciplines denounced by Descartes for their lack of veracity. It is the dynamic concept of truth which validates historical disciplines. All disciplines oriented towards unlimited nosse, velle and posse have in God, the absolute truth, their source; they further return to this source in circle and depend on it for their consistency. This means, for example in the field of jurisprudence, that the eternal and true right is right in temporal and historical clippings. In other words, the abstract natural right must be substituted with the temporal one. Further the concept of a historical development of natural right commands credibility.

Vico therefore accepts a distinction between early and later natural right (ius naturae prius and ius naturae posterius) ${ }^{63}$, based on distinct mental stages and applied to distinct realms of life. Whereas the early natural right, viewing man as sentient-individual creature occupies with questions of marriage and descent, the later natural right, basing itself on the cognitive faculties of man discusses his social and political life. It thereby develops the previous norms

61. Opere di G. B. Vico, vol. 2/1, p. 42.

62. Opere di G. B. Vico, vol. $2 / 1$, p. $49 \mathrm{f}$.

63. Opere di G. B. Vico, vol. 2/1, pp. $76 \mathrm{ff}$. 
and customs especially in reference to state and society. Both - early and later natural right - evidence the historical natural right of the peoples; both describe the common, not individual, history of peoples. Vico's pointe is: both are realisations of a conatus (vis veri); whereas one had its impulse in senses, the other had it in reason. The sense-based authority of the previous natural right is revised and substituted by a rational authority. Both, however, are valid historical expressions of the eternally true right. Consequently, it is the common sense (understood both as sensuous and rational), not individual claims, on which authority or lawfulness is founded. Vico develops this concept in the New Science and postulates a theory of three successive ages in the life of nations. However, in all his writings Vico lays emphasis not on the changing phenomena, but on the eternal order or structure lying behind them. For the conformity of mind to the latter alone can bring forth truth: Verum gignit mentis cum ordine conformatio; certum gignit conscientia dubitandi secura. Ea autem conformatio cum ipso ordine rerum est et dicitur ratio ${ }^{64}$. The truth, for example, about the legal system shall be known only when its very constitution is recognized as the true order. Any postulate on the rationality of a legal order, according to Vico, will fall short of truth if it does not acknowledge its constitutive moment. This is applicable not only to all disciplines, but also to the constitution of man himself. And this leads us to the anthropological import of Vico's concept of order.

\section{II.2. Order as a philosophical-anthropological concept}

From the perspective of a philosophical anthropology Vico's concept of order is distinguished for two features: the emphasis placed on phantasy and the development of humanity traced to its very beginnings. The importance attached to the beginnings is testified by the workings of phantasy in the birth and growth of humanity. By placing phantasy at the emergence of humanity Vico on the one hand founds a sense-based, non-dualistic anthropology, and on the other hand incorporates the metaphysical-theological notions in the autopoietic conception of mind. Both these points are discussed below in the structure of phantasy. The action of phantasy in the beginnings of humanity is demonstrated in the genesis of ideas and of society. They take concrete form, for example, in the political systems from antiquity to our own days. Vico is

64. Opere di G. B. Vico, vol. 2/1, p. 35 . 
interested in providing a credible explanation of the variety of socio-political systems by tracing them back to the structure of human behaviour. Cultural variety has its basis on the primitive formalism of thought, and the concept of phantasy serves to substantiate this claim. Vico's key to this explanation is the imaginative universal, the primordial product of a tripartite phantasy.

In the following I discuss (i) the structure of phantasy which enables (ii) the production of imaginative universals. How these imaginative universals order life is demonstrated in their simultaneous genesis with the society. The pre-history of humanity, according to Vico, can be described as (iii) a structural development in three epochs: that of the gods, the heroes and men. Characteristic of the first two epochs is the imaginative universal, whereas the intellectual genera correspond to the age of men.

(i) The structure of phantasy. Vico's concept of phantasy implies three different faculties of mind, namely ingeniousness, imagination and memory (ingegno, fantasia \& memoria) ${ }^{65}$. Their close interaction and unity can be adequately explained if one understands phantasy as the faculty of knowledge leading to action. The term faculty (facultas) signifies not simply power, but above all spontaneity and productivity 66 . Consequently invention, memory and imagination are attributed spontaneous and productive activity ${ }^{67}$, they are hence compared to the pure act in God. That the humans are equipped with a tripartite phantasy means that the core of human actions alike the pure act in God is constituted of creative productivity. In as much as the memory preserves and reproduces the sense images perceived in the past it fulfills its own share of creative production. "Memoria in this sense is the power to bring to mind what is not before the mind, to find in the here the not-here and in the now the not-now"68. The rest is done by imagination and ingeniousness. Whereas the former invents things by transformation and imitation, the latter discovers the new by joining together the discordant and separate into a unity. Remembrance, transformation, imitation, invention, discovery and unification constitute the different moments of the faculty phantasy. To these Vico traces the origin of the general concepts or imaginative universals which

65. Compare Liber metaphysicus, ch. 7. For a more detailed discussion see P. G. Pandimakil, Das Ordnungsdenken bei G. B. Vico, pp. 154ff. Also: Donald Philip Verene, Vico's Science of Imagination, esp. ch. 4.

66. Facultas is "expedita, seu expromta faciendi solertia"; further: "una prontezza di operare”, Liber metaphysicus, pp. 118/119, 170/171.

67. New Science 819.

68. D. P. Verene, Vico's Science of Imagination, p. 104. 
order the human world. Thus the human world begins with the united action of the tripartite phantasy69.

In fact the first general concepts of thought emerge from the aforesaid initial moments of imaginative action, and knowledge begins with such sensebased concepts. The very first knowledge is imaginative and interpretative, and hence the New Science lays emphasis on the imaginative genera against the intelligible universals. Whereas the imaginative universals (caratteri poetici, generi fantastici or universali fantastici) are characteristic of the first two epochs of humanity, namely the age of gods and the age of heroes, the intelligible universals (generi intelligibili or universali intelligibili) typify the thought pattern of the third epoch, the age of men. But it does not mean that the imaginative genera ceased to exist or should do so in the last epoch. On the contrary they do form part of humanity, and an absence of phantasy will be detrimental to mankind's further existence. This is also the reason for Vico's assertion that the primary faculties of mind are corporeal and that thought in its initial stage has no other means of expression than phantasy, nor that humanisation would start without phantasy. The theory of the imaginative universal covers, thus, both the epistemological and existential spheres of life.

Knowledge engendered by phantasy is not rational, but corporeal 70 . It comes closer to sensation than to reason, in as much as phantasy belongs to the primary operation of the mind. However, in allotting phantasy to the domain of sensation Vico does not, unlike Hobbes ${ }^{71}$, consider it common to all animals. It is for him, alike for Kant ${ }^{72}$, the active faculty which transcends the limits within which all animals are held. Phantasy, hence, becomes the distinctive feature of humanity. This amounts to say that the knowledge brought about by phantasy not only belongs to the domain of pre-rationality, but also that it is indispensable to human existence. For knowledge expressed in imaginative genera serves both mathematical operations as well as practical life. Vico's enquiry into the beginnings of humanity proves this claim by explaining how the first humans produce the imaginative universal or mythos of Jove which orders their lives ${ }^{73}$. Evidently Vico's concern is with the begin-

69. Liber metaphysicus, pp. 127, 134, 216, etc.; cf. also: New Science 376, 816.

70. New Science 699.

71. Thomas Hobbes, Leviathan (vol. 3 of The English Works of Thomas Hobbes, ed. William Molesworth, John Bohn, London 1839), pt. I, chs. 1 \& 2.

72. Immanuel Kant, Mutmasslicher Anfang der Menschengeschichte, A 7 (Werkausgabe, ed. Wilhelm Weischedel, Suhrkamp, Frankfurt a. M. 1977), vol. 11/1, pp. 88-89.

73. The core of Vico's imaginative universal consists in a theory of metaphor set at the beginning of knowledge and action, whose specific character and full implications shall be discussed under the following heading, the very first beginning. 
nings and accordingly the imaginative universal plays at this stage the central role both in theoretical and practical life. The intelligible universal, the generic concept of Aristotelian logic, serves only as a contrast.

Vico's thesis is that human action, and eventually humanity itself, begins with the production of images and metaphors. Action signifies here the mental productivity that engenders societal orders capable of acting upon day to day life. Images provide the form according to which actions are ordered. And it is the ordering of experience that produces the human world. Consequently, Vico's concept of action is closely linked with the making of history which according to the New Science transcends the conscious and rational intentions of man. Historical rationality can be understood only as poiesis. For what is produced, are images or ideas which normatively act upon human behaviour 74 .

Thus by placing phantasy at the very beginning of humanity Vico can assign man a place beside God: "ut Deus sit natura artifex, homo artificiorum Deus"75. It is the phantasy which makes man the author of the human world: questo mondo civile egli certamente é stato fatto dagli uomini76. But how did man make this world? Vico finds the answer in the function of phantasy in human thought and action.

(ii) The very first beginning. Vico's description of the function of phantasy at the very beginnings of humanity is set against an imaginative empirical scenery that can serve as the zero hour: the time immediately after the biblical deluge. The choice has the advantage that at this point humans possess nothing other than sense faculties, and hence are described by Vico as the giants (giganti) ${ }^{77}$. Endowed with robust sense and powerful phantasy man faces an inimical nature. Thanks to images engendered by phantasy he succeeds to assert himself, to order his passions and to establish a life-style. The normativeness and legitimacy of this primitive humanity is founded alone on the power of autopoietic images. They constitute the source of human customs (umani costumi) or institutions like religion, marriage and burial. Being principles (that is to say, generative conditions) of enduring life-style they are to be counted as anthropological constants. There exists a correspondence between Vico's primordial institutions, anthropological constants and Kant's

74. Compare New Science 376; Ferdinand Fellmann, "Der Ursprung der Geschichtsphilosophie aus der Metaphysik in Vico's Neue Wissenschaft”, in: Zeitschrift für philosophische Forschung 41 (1987) 43-60, here: p. 56.

75. Liber metaphysicus, p. 126.

76. New Science 331.

77. Compare New Science 369, 370, 374, 375. 
metaphysical ideas. I shall take this correspondence into account in the following discussion on the simultaneous genesis of ideas and society.

According to the New Science the genesis of the first idea or imaginative universal or fable occurs as follows: “... when at last the sky fearfully rolled with thunder and flashed with lightning, ... [t]hereupon a few giants, who must have been the most robust, and who were dispersed through the forests on the mountain heights ... were frightened and astonished by the great effect whose cause they did not know, and raised their eyes and became aware of the sky. And because in such a case the nature of the human mind leads it to attribute its own nature to the effect, and because in that state their nature was that of men all robust bodily strength, who expressed their violent passions by shouting and grumbling, they pictured the sky to themselves as a great animated body, which in that aspect they called Jove, the first god of the so-called greater gentes, who meant to tell them something by the hiss of his bolts and the clap of his thunder". "In this fashion the first theological poets created the first divine fable, the greatest they ever created: that of Jove, king and father of men and gods, in the act of hurling the lightning bolt"78.

First of all, Vico attempts in this passage to set the phantasy so close to sensation that the genesis of idea can be traced back to its very roots. According to the verum-factum principle developed in Liber metaphysicus knowledge amounts to a creative activity of mind79. Interpreting now action as productivity of mind Vico succeeds in establishing a relation between thought and sensation. From a purely epistemological perspective one might ask: what should the mind imagine in order to know the outside world? Or even, if knowledge of external reality is possible. Vico, unlike Descartes, does not put these questions, but asks: how the mind imagines in order to know? In other words, Vico does not ask why, but how knowledge is possible. The enquiry about the manner of knowledge leads to the answer that knowledge begins with the productivity of images or metaphors or imaginative universals. Consequently thought is transposed to the realm of action; and is understood as corporeal thought. This is the gist in defining phantasy as the faculty of knowledge leading to action.

Although phantasy is close to sensation, it's activity differs from that of the senses. Unlike sensation, which is characterized by immediacy and parti-cularity, phantasy possesses the very capacity to transcend these. It is evidenced in the activity of sensation common to animals and humans. Animal sen-

78. New Science 377 \& 379.

79. Liber metaphysicus, ch. 1 , sections $1-2 \& 4$. 
sation consists in a current of impressions in "which each new sensation cancels the last one"80. Similar was the plight of the first men whose minds were immersed in the particular. Thanks to phantasy a universal is formed out of the particular, rendering hence meaning to the immediate flux of sensation. "Meaning can be achieved only if a sensation can become a particular that is not cancelled by the presence of the next sensation. The mind can have something before it through its power to produce an identity. A sensation is apprehended as the being of the other sensation in the motion of the flux. The time of the flux is cancelled by a locus within itself. A single sensation becomes a permanent reference point of the flux of sensations which now have their being in it. Through this fixed point of sensation, or particular, the meaning of the flux can be repeatedly grasped"81. Precisely this is done in the formation of an image or metaphor: the meaning of the whole is found in a particular which is fixed and found again. According to Vico, fixation of the flux of sensation results through the gesture or mute sign, the primary form of speech preceding all thought 82 . This is not an issue of analogy, but of identity. Identity constitutes the fundamental principle of Vico's theory of myth, and for this reason myth deserves the appellation of vera narratio or true speech. For the myth as imaginative universal identifies the particular sensation with the totality. Hence univocalness is assigned to the first myths. "In the fixing of sensation the meaning of the whole of the flux is found again in the single sensation. In this way a universality is achieved through the particular. An identity is made."'83

In the New Science Vico introduces the image of Jove as the first po(i)etic character enabling the fixing of sensation among the first men. The particular sensation that brings a halt in the flow of sensations is thunder and lightening and the consequent corporeal reaction aroused by this physical phenomenon among the giants. According to Vico the first men imagined the sky to be an animated body which communicates with them through the signs of thunder and lightening. "This first thought is the thought of Jove as an active moving body that shouts back to their shouting with the original shout. Jove calls attention to himself as the largest of the giganti by his powers of light and

80. New Science 703.

81. D. P. Verene, Vico's Science of Imagination, p. 82. Verene's interpretation is based on the process of Wiederfinden (finding again) described by Ernst Cassirer, The Philosophy of Symbolic Forms, III, 108 \& 124.

82. New Science 446.

83. D. P. Verene, Vico's Science of Imagination, p. 83; cf. New Science 403. 
sound. The divine arrives in noise. His body flashes and shakes and the bodies of the giants shake with sympathetic motion out of fear. Jove is not an alter ego, but a vast body to be feared". ${ }^{84}$ In fact, the first thought is the discovery or better the invention of the Other. It is the result of the giants' attempt to integrate the unknown external phenomena in their world of experience. The primitive man explains the natural phenomena by attributing their causes to a being like himself 85 . He rediscovers the image of Jove every time the sky thunders and lightens up. Phantasy thus provides the means to order the experience.

Further, by discovering Jove in the skies the giants discover themselves. The self-discovery of man begins with the awareness of sky as a body of different order. With this first distinction of thought, in capturing the difference between earth and sky, the primitive man comes to understand where he belongs to: he is of the earth. Moreover he recognizes the other sphere of the universe which the vast body of Jove occupies. Once this distinction forms part of the consciousness, it is possible to order the realities of the world. Such ordering corresponds to the pattern of thought or mentality of the first epoch ${ }^{86}$. This takes us to the genesis of society which cannot be separated from the spontaneous production of ideas.

Alike idea, society also emerges thanks to phantasy. Both can be traced back to the anthropological constant, fear. Fright or fear, spavento or timore, occasions ideas and institutions on which society is founded. Neither the imaginative universal nor the institutions arise as answers to particular problems raised by the humans, they are spontaneous creations; they have their roots in human passion. Schematically the correspondence between ideas, institutions and anthropological constants can be given as follows:

\begin{tabular}{|l|l|l|l|}
\hline Metaphysical Ideas & God & Freedom & Immortality \\
\hline Institutions & Religion & Marriage & Burial/property \\
\hline Anthropological Constants & Fear & Fear and Shame & Fear, Shame and Embarrassment \\
\hline
\end{tabular}

84. D. P. Verene, Vico's Science of Imagination, p. 84; cf. New Science 377.

85 . It is the result of human ignorance, for "man makes himself the measure of all things" and "judges by what is familiar and at hand". New Science 120, 122.

86. See below: The Three Ages of Man. 
According to Vico's description in the New Science, it is fear which initiates religion, leads to marriage and is associated with burial87. Although fear is manifested differently in all these three cases, it forms the common denominator in the emergence of patterns of behaviour which constitute the institutions. In the case of religion the fear of Jove is quite real and tangible, for to the giants the sky "was no higher than the mountain peaks" 88 . So the fear of their own bodies causes them to apprehend the vast body of Jove itself. In the case of marriage the giants are afraid to satisfy their lust in the sight of heaven, and hence retreat into the caves, each one with his companion thus giving rise to a constant relationship ${ }^{89}$. Fear forms also part of the institution of burial, for sacredness is associated with the burial places. Moreover there is the real danger of losing one's habitat, which eventually is secured, argues Vico, with the burial: "by the graves of their dead the giants showed their dominion over their lands" 90 . Thus the fear of losing one's self (body), one's companion and one's possession is essential to the emergence of the primordial institutions.

The mortal terror or fear which Vico here addresses is sui generis: "not fear awakened in men by other men, but fear awakened in men by themselves"91. This autopoietic fear touches their whole being, but its source is an "immediate beyond": It is present every time the sky thunders and lightens up ${ }^{2}$. And it builds up the mind and body of the giants in such a manner that they become humans. It is a formative passion which imparts motion to their bodies: they do not flee away from, but mimetically reproduce the celestial motion. This bodily motion is reflected in gesture which, as was mentioned above, helps to fix the flow of sensations and enables them to apprehend the primordial distinction between sky and earth. Further: "The ability to fear and fear again in the same way produces a common point of focus, an object, and a common form of feeling among the giants. They feel the same thing in the same way. In this constancy of feeling induced by fear human society is born". ${ }^{93}$ The birth of society out of the primordial fear renders man a place in the universe; man after the biblical deluge was 'thrown' in the world, he was disoriented. All this comes now to an end: man defines himself against the

87. New Science 712, 1098 \& 529.

88. New Science 379.

89. New Science 504.

90. New Science 531.

91. New Science 382.

92. New Science 387.

93. D. P. Verene, Vico's Science of Imagination, p. 91. 
Other, and consequently he is no more a nomad. Thus the primordial fear transforms man both externally and internally.

Vico argues that men after the biblical deluge lacked the fear of God, and without the fear of the gods they were giants. Once fear was instilled, they assumed normal stature: "It was by becoming imbued with this cleanliness of body and this fear of gods and of fathers - in both cases a fear we shall find amounting to terror in the earliest times - that the giants diminished to our normal stature" 94 . Fear, working on body, is also the beginning of divination and sacrifice for which the sacred ablutions are prescribed. But the same fear helps also in engendering the notion of goodness. It is the result of a transformation process, a transference of meaning alike the formation of the grammatical conditional95. According to Vico the giants feared "the false divinity of Jove because he could strike them with lightening"96, but he did not. "From the first great benefit he conferred on mankind by not striking it with his bolts, he received the title Soter or saviour"97. Confronting the possibility with the actuality engenders meaning. Transformation of body represents also mental transformation and altered forms of relationship with oneself and the outside world.

This point is of importance in the theological context in which Vico narrates the genesis of ideas and society. The genesis of pagan religion is a providential act. Since fallen man lost the idea of God, he lost his nature, deteriorated to the state of animals, and providentially created gods for himself out of fear and curiosity, both of which are products of ignorance. Fear, curiosity and ignorance constitute thus the psychological basis of the primitive religion. They are the providential means to make a sapiens out of the stultus ${ }^{98}$. By fearing false divinities which he himself invented man slowly recovers his nature.

From a theological perspective the recovery of human nature is the issue also of the primary customs of marriage and burial. Alike religion marriage has its roots in fear. But Vico now introduces a new element, shame which working together with fear produces the institution of marriage. Shame can be considered as an innate impulse of man; the autopoietic idea of God enables man to give new direction to the natural impulse of shame. The result is

94. New Science 371; see also $369 \& 381$.

95. Compare Ferdinand Fellmann, "Vico und Kant auf dem Wege zur historischen Vernunft" (unpublished manuscript, Münster 1990), p. 13f.

96. New Science 385.

97. New Science 379. 
that humans become modest and moderate in the exercise of their sexuality. Precisely this exercise of shame under the fear of gods signifies for Vico the first act of human liberty 99 . Settlement follows such modest unions blessed by the divinity. Thus religiously sanctioned ownership of property is represented by the customs of burial. For a human society both incest and unburied decaying bodies will be abhorrent ${ }^{100}$. Or, in other words, it is absurd to talk about institutions or society of giants. Burial customs ascertain, according to Vico, the sovereign dominion of primitive man over his lands. And consequently the immortality which the custom of burial perpetrates is more that of the family rather than that of the soul. Vico attaches so great an importance to the custom of burial that he finds humanitas as a derivative of humare, to bury101.

Briefly, the primitive man wandering about the forests discovers himself thanks to his phantasy which pictures the sky as the vast other body communicating with him in thunder and lightening. The image of Jove born out of autopoietic fear brings an end to the nomadic life of man binding him to a place and to a person. Vico's emphasis on the primordial fear which orders human life with the appearance of institutions seems to suggest that it is the necessary condition in any first thought. However, one might ask how these institutions could succeed in establishing an enduring form of life. Or, how phantasy images could render normativeness and legitimacy to behaviour? The answer consists in the specific nature of human activity: the primitive man believed unreservedly in the self-made images: fingunt simul credunt$q u e^{102}$. It is this belief which constitutes the most effective means in the production and conservation of life-styles. That is to say, a reflective transparency is not an attribute of Vico's phantasy, and consequently it defies all manipulation. Further, it is a collective social organ, unlike the artist's individual imagination, and does not distance itself from the subject. And this enables Vico to describe the development of humanity in terms of a history of mentalities in which patterns of thought and social behaviour correspond each other.

(iii) The Three Ages of Man. In consonance with the above description of the emergence of humanity, the New Science provides a developmental history of human nature. Unlike his contemporaries Vico attributes this deve-

98. See: M. Lilla, G. B. Vico, p. 161; also below p. 355 f.

99. New Science 1098.

100. New Science 336 \& 337.

101. New Science 12, 357.

102. New Science 376. 
lopment to a human nature functioning differently in the various epochs. "These are: (1) The age of the gods, in which the gentiles believed they lived under divine governments, and everything was commanded them by auspices and oracles, which are the oldest institutions in profane history. (2) The age of the heroes, in which they reigned everywhere in aristocratic commonwealths, on account of certain superiority of nature which they held themselves to have over the plebs. (3) The age of men, in which all men recognized themselves as equal in human nature, and therefore there were established first the popular commonwealths and then the monarchies, both of which are forms of human government"103. Each epoch is characterized by the particular human nature to which actions are referred. Thus feeling, thought and action of the primitive humanity is greatly different from that of contemporary man ${ }^{104}$. In taking account of this fact one not only avoids the pitfalls of ethnocentrism and anachronism, but also correctly interprets the correspondence between ideas and actions. For the various epochs of man signify forms of mind which legitimize and motivate actions.

The epochs or mentalities constitute a unity in as much as they epitomize the self-consciousness of men living in this period. This is demonstrated through a congruence of ideas, customs and actions ${ }^{105}$. The unity of each epoch is represented in the poetic characters, concrete expressions of the imaginative universals, which evidence the particular form of thought. Mythical form of thought is common both to the first and second epochs, whereas rational form of thought is specific to the third. This contrast between the last human nature against the first two does not mean a total separation of the natures, but only different perspectives. All together form the one human nature. Thus from a political perspective unreflected equality constitutes the hallmark of the age of the gods, war and division that of the age of the heroes and the reestablishment of equality that of the age of men ${ }^{106}$. Vico's interest lies more in accounting for the difference in human behaviour in various periods and cultures, by showing how the different attitudes do form essential part of humanity itself. This is the point in emphasizing the mythical form of thought specific to pre-historic humanity.

103. New Science 31.

104. New Science 375f.

105. New Science 368.

106. See Vittorio Hösle, "Vico und die Idee der Kulturwissenschaft" (Introduction to the German translation of Vico's New Science. In: G. B. Vico, Prinzipien einer neuen Wissenschaft über die gemeinsame Natur der Völker, transl. by V. Hösle \& C. Jermann, F. Meiner, Hamburg, 1990, vol. I, pp. XXXI-CCLXXVII), here p. CXL. 
The mythic form of thought engenders a truth whose evidence consists not in association (which has to do with alternation), but in identity (which has to do with simultaneity) exemplified by the image of Jove. Vico interprets this identity as a transformation of man into thing, precisely because he does not understand: "when man understands he extends his mind and takes in the things, but when he does not understand he makes the things out of himself and becomes them by transforming himself into them"107. By becoming the thing the mythical thought achieves an interpretation of the reality as a meaningful totality.

According to Vico the immediate correspondence between subjective sensation and mental image constitutes the truth of the senses, produced by the primitive humanity. Given its ignorance the humanity at this stage is capable of only such a production. But it is a formal truth in the sense of total identity between sensation and judgement. The formal truth of the myths is guaranteed by the truthfulness of the primitive human nature, or by its incapability of producing a mental image deviant from sensation. Such is the truth associated with Jove. The image of Jove and its truth can be challenged by other images produced by the same humans or the same images produced by a different set of humans. Vico's solution to the plurality of images in a single subject consists in the statement that "whatever these men saw, imagined, or even made or did themselves they believed to be Jove; and to all of the universe that came within their scope, and to all its parts, they gave the being of animate substance"108. By producing a uniform totality the mythical consciousness preserves its claim to truth. With regard to the plurality of subjects Vico introduces the concept of common sense, which is "judgement without reflection, shared by an entire class, an entire people, an entire nation, or the entire human race"109. The fact that all participate in the same mental image renders it true ${ }^{110}$, and makes it effective for the whole epoch.

In spite of this fact neither the mythical truth nor the mythical form of thought is comprehensible to us. For independent of any factuality to which the image might refer to, the mythical thought attributes an inner truth to the mental image. This is the specific characteristic of imaginative universal for which Vico considers it a po(i)etic truth. He writes, "if we consider the matter well, poetic truth is metaphysical truth, and physical truth which is not in conformity with it should be considered false. Thence springs this important

107. New Science 405.

108. New Science 379; see also: 120, 508 \& 702.

109. New Science 142. 
consideration in poetic theory: the true war chief, for example, is the Godfrey that Torquato Tasso imagines; and all the chiefs who do not conform throughout to Godfrey are not true chiefs of war"111. The point is that Godfrey is not an abstraction, but an ideal portrait, and the individual is identified with this ideal. The myth provides the ideal type to which individuals have to conform. Thus mythical truth attains the status of metaphysical truth: the individual does not have a being other than that of the type. It is this metaphysical character of the mythic form of thought which validates the actions of the primitive humanity in the first two epochs. In other words, a mythical rationality forms the basis of primitive thought and action.

However, expressions of mythic rationality differs considerably in the age of the gods and that of the heroes ${ }^{112}$. Whereas the men in the first epoch formulate imaginative universals out of the immediately experienced forces of nature or of physiology such as the thunderous sky and the sexual impetus, the heroes give form to human qualities ${ }^{113}$. There is a notable shift from the inanimate to the animate world, or better from the unqualified Other to the other person. Jove and Juno, Achilles and Ulysses, for example, represent respectively the poetic characters of each epoch. In general, men of the first epoch attribute a substantial equality to the whole universe, while the heroes of the second epoch emphasize the difference among men. They consider themselves to be of divine origin, and make this natural nobility 114 a point to distinguish themselves from the plebeians. The conception of equality in the age of the gods is, as already mentioned, unreflective in contrast to the same rational notion in the age of men. Thus the self-consciousness of humanity moves from credulity through assertiveness to reason. Parallel to this is also the development from a collective to individual consciousness all of which is expressed in the distinction between imaginative and intellectual universals.

In reasserting the imaginative universal Vico claims to reinstate the human nature in its entirety. For the three-part structure of human society would run the risk of disintegrating if the imaginative aspect is disregarded. This takes us to the political ethics of the New science, which challenges some of the rational theories of Vico's contemporaries.

110. That this participation can be understood as a common, corporeal motion is Verene's thesis discussed above, see p. 356

111. New Science 205.

112. New Science 31-40; 915-979.

113. New Science 933-934.

114. New Science 917. 


\section{ORDER AS THE UNITIVE CONCEPT OF VICO'S PHILOSOPHICAL ANTHROPOLOGY}

The discussion of the concept of order has been centred hitherto on the metaphysical, epistemological and anthropological aspects which account for both the cultural differences of humanity and the specificity of human nature. However, it is the socio-political moment that Vico emphasizes and the primary institutions are examined from this perspective. Consequently if we intend to speak of a unitive concept of order in Vico's anthropology it must explain how the aforementioned realms are integrated in it. Such an explanation seems possible at least on two grounds: the constancy and recurrence of history. History for Vico is both autopoietic and self-regulatory, but both its creativity and lawfulness are expressions of sapienza. And it is from the perspective of wisdom that order achieves the status of a unitive concept.

Vico attributes the emergence of the primary institutions to sapienza volgare or poetica. According to their manner of coming into being the "history of the institutions", which are "universal and eternal", proceeds "without human discernment or counsel, and often against the designs of men"115. The concept of ideal eternal history constitutes the highest generic term of order for Vico; it includes the notions of course and recourse as well as those of fulfilment and downfall. All these find their plastic expression in the image of the ideal state. Although the concept of an ideal state might be traced back to the Platonic Republic, Vico's defence of it seems to emphasize justice, which constitutes and preserves the society. Hence in conjunction with the concept of order the New Science proposes a political ethics, which even at the risk of ignoring the individual exalts the humanity as a whole.

But in what sense is Vico an ethicist? Not in the manner of Kant. His is not an ethics of duty, but a dogmatism of attitudes. Nonetheless the dogmatic framework provides important insights even for the modern society. In order to substantiate this claim I shall discuss the implications of Vico's socio-political ethics under the following headings: (i) Ideal eternal history as socio-political ethics, (ii) Political virtues and commonwealths and (iii) $A$ note of warning and reassurance. This should serve us to determine the extent of Vico's concept of order.

(i) Ideal eternal history as socio-political ethics. Vico explains the central position attributed to the ideal eternal history in the New Science as follows: 
"Now, in the light of the recourse of human civil institutions ..., let us reflect on the comparisons we have made throughout this work in a great many respects between the first and last times [-that is, between those] of the ancient and modern nations. There will then be unfolded before us, not the particular history in time of the laws and deeds of the Romans or the Greeks, but (by virtue of the identity of the intelligible substance in the diversity of their modes of development) the ideal history of the eternal laws which are instanced by the deeds of all nations in their rise, progress, maturity, decadence, and dissolution [and which would be so instanced] even if (as is certainly not the case) there were infinite worlds being born from time to time throughout eternity"116. This design of ideal eternal history is multidimensional. First of all it signifies the course the nations run, which Vico constructs after the model of Greco-Roman history. It is simultaneously both synchronic and diachronic; conformity and sequence constitute its two characteristic moments. In Vico's transformation the particular Greco-Roman account attains the character of a structural history narrated by the poetic or mythological characters such as Jove, Diana, Apollo, etc. Secondly, the ideal eternal history possesses a nomothetic dimension, which is confirmed by the recourse the nations run. Course and recourse proceed according to laws immanent in the corresponding societal structure. In accounting for the regularity of corsi $e$ ricorsi Vico introduces the medieval institutions which amplify the GrecoRoman model into European history. Thirdly, Vico claims the ideal eternal history to be universal, and thus makes it the model to understand and the criterion to judge the particular histories of various nations. The ideal historical process which extends to all never comes to rest until its end, namely the attainment of full justice is realized. Hence from a universal perspective the most salient feature of the ideal eternal history is its ethical dimension. Consequently the ideal eternal history which Vico employs as a model to interpret the particular histories of the nations should also serve as a guideline to humanity. In effect, it is a theoretical construct which not only orders the particular histories but also avails as the medium to understand them, and as such cannot but be pluridimensional.

How the pluridimensional model of ideal eternal history functions as an interpretative instrument is best demonstrated in the three-structure prehistory provided by Vico. The ideal history of the three ages of man can be schematically given as follows ${ }^{117}$ :

116. New Science 1096; my italics.

117. Numbers in square brackets refer to paragraphs in the New Science. 


\begin{tabular}{|c|c|}
\hline IDEAL/ROMAN HISTORY & NATURAL THEOGONY [7] \\
\hline \multicolumn{2}{|c|}{ BESTIAL AND FERINE STATE } \\
\hline Giants & Atheists [369] \\
\hline \multicolumn{2}{|l|}{ Process of Humanization: } \\
\hline \multicolumn{2}{|c|}{ THE AGE OF THE GODS } \\
\hline \multicolumn{2}{|l|}{ Formation of Family: } \\
\hline Religion & Jove [502] \\
\hline Marriage & Juno [511] \\
\hline \multicolumn{2}{|c|}{ Formation of the Sense of Property: } \\
\hline Settlements & Diana [528] \\
\hline Burial & Apollo [533] \\
\hline Cultivation & Vulcan, Saturn \& Vesta [549] \\
\hline \multicolumn{2}{|l|}{ Formation of State: } \\
\hline Asylums & Mars [562] \\
\hline Serfdom & Venus [562] \\
\hline \multicolumn{2}{|c|}{ THE AGE OF HEROES } \\
\hline \multicolumn{2}{|l|}{ Class struggle: } \\
\hline Aristocratic league & Minerva [589] \\
\hline First agrarian law (bonitary) & Mercury [604] \\
\hline Foreign wars and colonization & Neptune [634] \\
\hline $\begin{array}{l}\text { Second agrarian law (quiritary) } \\
\text { and right of connubium }\end{array}$ & [598] \\
\hline \multicolumn{2}{|c|}{ THE AGE OF MEN } \\
\hline Democracy and monarchy & {$[1008,1087]$} \\
\hline
\end{tabular}

What this schema of ideal eternal history presents is "a determinate sequence of human feelings of necessity and utility (i.e. judgements of common sense), and an equally determinate sequence of imaginative deities by which early man represents to himself" 118 . In understanding this sequence as "a rational chronology of the poetic history of gods"119 Vico assigns to the

118. Leon Pompa, Vico: A Study of the 'New Science' (Cambridge University Press, London 1975), p. 102. See also Mark Lilla, G. B. Vico. The Making of an Anti-Modern (Harvard University Press, Cambridge, Massachusetts 1993), esp. pp. 152-203. 
ideal eternal history the attribute of an apodictic a priori ${ }^{120}$. As a result the ideal eternal history can not only interpret but also foresee the particular historical order of any nation, once the "proper times and places" of the present institutions and "the human necessities or utilities of social life" are given. For "the course of the institutions of the nations had to be, must now be and will have to be" according to the ideal eternal history set by the New Science ${ }^{121}$. This conception of the ideal eternal history as an absolute model of development affirms that the particular histories of nations formally conform to the ideal order and it is to be found partially in the manifold histories of various nations ${ }^{122}$. Consequently the ideal eternal history can be constructed from the empirical facts known to us, and it obeys laws verifiable in the social history. In the New Science Vico constructs the primary stages of the ideal eternal history following the ideal-typical pattern provided by the poetic characters. The construction of that part of ideal history governed by the imaginative universals is the greatest credit Vico justly claims for his science. But how can this partial reconstruction of the ideal history be of paramount importance to humanity? The answer consists in Vico's political ethics.

(ii) Political virtues and commonwealths. The context against which Vico's political ethics emerges to the forefront is the theological-metaphysical dimension of the New Science. Vico's giants, the "founders of gentile humanity"123, represent the fallen man deprived of rationality, customs and piety. With the introduction of the fear of gods, and the consequent emergence of customs or institutions, humanity exercises an imaginative rationality or poetic wisdom on which the first two epochs are founded. Life in accordance with these institutions is necessary so that a political society comes into existence. The age of the gods marks the important phase of the crystallisation of human institutions -religion, marriage and burial/property- which precede any political contracts. This is the gist of Vico's answer to the political theorists of his time like Thomas Hobbes when he writes: "without religions no commonwealths can be born, and if there were no commonwealths in the

120. That is to say, "ein absolutes Entwicklungsmuster ..., von dem a priori gewiß ist, daß es dem empirischen geschichtlichen Wandel zugrunde liegt" V. Hösle, "Vico und die Idee der Kulturwissenschaft", p. CXV.

121. New Science 344,344 \& 348.

122. "This was the order of human institutions: first the forests, after that the huts, then the villages, next the cities, and finally the academies. ... The nature of peoples is first crude, then severe, then benign, then delicate, finally dissolute" New Science 239, 242; see also 22 \& 241.

123. New Science 369. 
world there could be no philosophers in it"124. In other words, a rationality of 'common sense' must precede the rational politics.

Senso comune or common sense, already referred to as the social organ of nascent humanity ${ }^{125}$, has a theological basis. It is "the social expression of divine conatus, and begins in a drive to share experiences with others"126. In this connection conatus represents the divine force or drive present in the fallen man to lead him indirectly to his good. It is individual in character, but applied to the society achieves now a wider meaning. The individual choices of fallen man remains irrational, stultus; they cannot lead him to his good. But once the choices arise from common instincts producing a common image affecting all alike they can serve as pointers to truth, freedom and well-being. Hence Vico writes: "Uniform ideas originating among entire peoples unknown to each other must have a common ground of truth. This axiom is a great principle which establishes the common sense of the human race as the criterion taught to the nations by divine providence to define what is certain in the natural law of the gentes"127. Common sense as an instrument of discernment prompts man to society by co-ordinating his actions and thus engendering the institutions. Once in society these institutions achieve constancy and hence can be retraceable in history. The system of institutions represents the social wisdom which is linked to individual common sense. It is the working of common sense in different levels which Vico finds in the emergence of political virtues attributed to the "good honest men" who constitute "the true natural aristocracy"128.

Vico's thesis that a natural aristocracy forms the basis of civic society has various implications. In exalting the nobility of spirit and in considering it as the distinctive mark of primitive political society he takes sides with a social order which emphasizes the mental sphere. The perfection and permanence of the society would thereby depend on how far the institutions are capacitated to form and command the spirit of man. Unlike the rationalists of his time what Vico discovers and advocates as the inevitable force to form the society is the autopoietic image, such as that of Jove. It is important to note how this image works in forming man. Unlike in the Platonic allegory of the cave where one comes across the ideas on walking out of the cave and encounte-

124. New Science 179; see also 1110.

125. See above p. 358.

126. M. Lilla, G. B. Vico, p. 156. See also above: II.1: "Order as a metaphysical-theological concept".

127. New Science 144-145.

128. New Science 1097. 
ring the Sun of truth, the formative virtues of Vico's civic republic are acquired in the cave. The political virtues of the founders of the commonwealth are intimately tied to their concrete lives led under the tangible image of Jove. Permanence in the terror of Jove engenders permanence at a place and with a partner. Thus Vico overcomes the mere ideality of the Platonic State. Consequently the institutions of the primitive humanity undergo a functional interpretation: they answer to the needs of man. But Vico takes them farther. Although the institutions respond to the individual needs of each person, they lead him beyond himself and his punctilious existence. That is to say, the emergence of political society, or of political virtues, cannot be fully explained by referring back to human needs. There is something 'more' to it which Vico attributes to the divine providence.

Irrespective of how one would interpret Vico's concept of providence, the political ethics of the New Science envisions an unknown and unintentional process whose primary end is "to preserve the human race upon this earth" 129 . And this is possible only by establishing a social order with firm basis on human creativity and aspiration. The argument can be expressed succinctly as follows: "without order (which is to say without God) human society cannot stand for a moment"130. And this truth is verified in the feral wanderings of fallen man after the deluge. Deprived of order men were doomed to live like wild animals. To save mankind from this bestiality "divine providence initiated the process by which the fierce and violent were brought from their outlaw state to humanity and by which nations were instituted among them. It did so by awaking in them a confused idea of divinity, which they in their ignorance attributed to that to which it did not belong. Thus through the terror of this imagined divinity, they began to put themselves in some order"131. The result of such an order was the family republics.

The rudimentary form of political organization which the primitive humanity could bring forth is conceived as the result of the constancy of its institutions. What provides this constancy? Vico writes: "Thus providence ordained certain household commonwealths of monarchic form under fathers (in that state princes) best in sex, age, and virtue. These fathers, ... must have formed the first natural orders, as being those who were pious, chaste, and strong" 132 . The first 'political' organization was the family headed by the best

129. New Science 1108.

130. New Science 1100, my italics.

131. New Science 178, my italics.

132. New Science 1098; see also 516; my italics. 
man. The fallen humanity attains a socio-political structure when it reacquires the virtues of the senses. It must have been these virtuous men, argues Vico, who became the pillars of the civil sovereignty. Consequently the family, not the feral state of humanity, forms the basis of polity. Unlike other socio-political theorists of his time Vico interposes family between the feral state and the political order. It would only amount to anachronism to consider that solitary man passed directly to polity; formation of cities was preceded by family republics. Since families could not be formed without religions taming man through shame and teaching him his duties, the insistence on family confirms also the order of events which Vico discovers in the ideal history133.

At the point of transition from family republics to heroic commonwealths Vico places asylum which shows also his deviance from classic and contemporary political theorists. Discarding equally the Aristotelian view that family and polity are natural extensions of human sociability and the Hobbesian position that politics pacifies human bellicosity, the New Science describes that not all of the humanity lived in family republics, a part remained still giants and challenged the establishment. Consequently there arose two classes of families: those who could resist the unruly and those who had to flee from them. "Thereupon the strong, with a fierceness born of their union in the society of families, slew the violent who had violated their lands, and took under their protection the miserable creatures who had fled them" 134 . However due to their crude mentality the strong could not consider the weak their equals which occasioned the establishment of serfdom, and consequently there emerged the two class society typical of the heroic republics. From the perspective of a political ethics it is important to note that the strong in the family republics not only identified nobility, beauty and virtue but also appropriated them exclusively to themselves. Their unwillingness to recognize the political virtues of the weak is reflected in the poetic character, Venus. For there are two Venus according to the two different representations, one by the heroes and the other by the serfs ${ }^{135}$. In spite of the birth of a political family thanks to the reacquisition of piety, modesty and cult (of the dead) the first republic is imperfect for its lack of common interest and ignorance of political equality. It should therefore develop further, and the next stage is represented by the heroic commonwealths.

133. See above p. 364.

134. New Science 553.

135. New Science 560, 568-569, 579-581; see also M. Lilla, G. B. Vico, pp.176-181. 
The heroic commonwealths alike the heroes themselves are intermediary stages, and hence do not possess fully the political virtues. Although the hero is no more fearful but self-assertive, his sense of self-consciousness and selfsufficiency often borders on cruelty, rigidity and injustice. Due to his ignorance he cannot comprehend the injustice and economic inequality against which the serfs rebel. They want to share with the heroes equally in religion, marriage and property in a manner that goes beyond the extended family structure, and the heroes are unwilling to comply with this demand. Vico sets at this point the orders of the nobles, which emerge out of private interests.

"For ..., under pressure of emergency, the heroes must by nature have been moved to unite themselves in orders so as to resist the multitudes of rebellious famuli. And they must have chosen as their head a father fiercer than the rest and with greater presence of spirit. Such men were called reges, kings, ... Such was the generation of the heroic kingdoms. And since the fathers were sovereign kings of their families, the equality of their state and the fierce nature of the cyclopes being such that no one of them naturally would yield to another, there sprang up of themselves the reigning senates, made up of so many family kings. They found that, without human discernment or counsel, they had united their private interests in a common interest called patria, which, the word res being understood, means "the interest of the fathers". The nobles are accordingly called patricians, and the nobles must have been the only citizens of the first patriae, or fatherlands"136. In order to safeguard their privileges against the serfs the 'solitary sovereigns' align together in orders based on nobility, a providential event leading to the formation of an independent polity.

The second form of commonwealth exemplifies the development from a biological family to a political structure, an aristocratic league, and consequently the interests safeguarded are not motivated by familial affiliation. Vico's emphasis lies in verifying the Roman political system, but he also advances the hypothesis that this political structure is reflected in the economic class system of heroes and serfs. Unlike in the family republic the heroic virtues of strict authority, vigilance and strength produce in the second republic both external and internal conflicts. That the aristocratic league would employ the rule of force against all outside it is demonstrated by the external conflicts: wars and colonization, which however brings in positive results such as commerce, military and government ${ }^{137}$. Rule of force is the characteristic of

136. New Science 584.

137. New Science 637-639, 132. 
this period, which for Vico forms part of the natural development in establishing equality. Thus the plebs, acquiring self-consciousness, demand equality with the heroes. Their demand is not easily granted. The internal conflict owing to the non-recognition of equal rights for the serfs slows down momentarily by the introduction of what Vico calls 'the first agrarian law'138, a social contract which grants partial ownership to the plebs. Politically the importance lies in its trans-familial structure. Vico would now conceive the plebs as an oppressed but politically organized group capable to defend their rights. A society of two classes each vying for public power is the political scene of the heroic commonwealth. The conflict ends when the plebs are granted connubium and thereby the full property rights. From the perspective of a political ethics the second commonwealth is of importance on two accounts: the emergence of law and the formation of a sense of public interest. None of these is planned by the parties concerned, but both introduce them into a socio-political order wider than they hitherto imagined or lived. The heroic virtues are necessary to defend and consolidate the primitive institutions. But even the heroes have to go farther in order to achieve full humanity: they have to recognize the non-heroic virtues of the weak, -and have to count the serfs as their equals. With this begins the last and final commonwealth.

The civil commonwealth marks the endpoint of humanization. "In such commonwealths the entire peoples, who have in common the desire for justice, command laws that are just because they are good for all"139. Although this description of the civil commonwealth is scanty Vico makes the point that with the achievement of rational principles man has reacquired the status of sapiens. Consequently the civil commonwealths function with a different set of rights and laws than that of the previous ones. Being intelligent, modest, benign and reasonable man now recognizes for laws conscience, reason and duty. A rough social equality is recognized, and the laws are applied with greater attention to particular cases. Such a civil commonwealth "impassioned for justice" was the ancient Roman republic in the time of Scipio Africanus. Roman republic constitutes, in effect, the concrete realization of the ideal civil commonwealth envisioned by Vico. But the Roman republic fell, and Vico draws from it conclusions applicable to the whole humanity.

(iii) A note of warning and reassurance. In considering Rome as the paradigmatic commonwealth Vico makes a subtle distinction between the early and later republics. It is the first republic of heroic families which he praises,

138. New Science 597f,; for a detailed description see M. Lilla, G. B. Vico, pp. $187 \mathrm{f}$. 139. New Science 1101; see also 918, 931, 935-936. 
and against which the later republic is evaluated. The praiseworthy model of Roman republic consists of Rome rising from patriarchy to monarchy and ending with the conversion of Constantine, and the consequent providential introduction of the 'true religion'. According to Vico this republic is governed by traditional wisdom, a principle radically different from that employed in the later republic, namely reason and liberty. Vico asks how Rome could have fallen when it in fact attained the peak of civilization, when it was the epitome of political virtues. His answer is an attempt to point out the dangers inherent in the process of political liberalization and enlightenment.

Among the various reasons to which the fall of Rome is attributed the most important for Vico consists in "the barbarism of reflection" which represents the ultimate stage of decadence of the civil commonwealth. It begins with "each man thinking only of his own private interests" and living "like wild beasts in a deep solitude of spirit and will, scarcely any two being able to agree since each follows his own pleasure or caprice". Self-centredness is the basest level of any society, for it is where the common interest of all shrinks down to the interest of a single individual. Against this rational individualism and solitude of feeling and willing Vico finds only one effective remedy: returning to the primitive simplicity, so that man may become again "religious, truthful and faithful. Thus providence brings back among them the piety, faith, and truth which are the natural foundations of justice as well as the graces and beauties of the eternal order of God"140.

However this drastic step is to remedy the progressive decadence implicit already in the civic commonwealth. In spite of the fact that the human age is dominated by the ideas of equality and reason the very rational and egalitarian state can indirectly cause a situation which adversely affects the common interest. For when the popular liberty includes all, each one's share in the public sphere is reduced ${ }^{141}$. Added to it is the mellowing of sentiments which draws the individual back to his family. Consequently a new kind of social individualism appears against which the civic republic is unable to compete. This is also because philosophy which served the first republic by carrying on the work of religion is rendered incapable by its association with rationalism and skepticism. Vico's point is that persuasive authority will be endangered when the ideas of reason and freedom take predominance in human life. For man would question the ideas he hitherto took for granted.

140. New Science 1106.

141. Compare New Science 621; also $1101 \mathrm{ff}$. 
And in the present case these are the primary institutions -religion, marriage and property- upon which the civil commonwealth is founded.

In the final portion of the New Science Vico argues that providence would not allow a sudden collapse of the civil commonwealth and would provide a monarch to bring man back to his senses. Introducing thus monarchy as a cure for civic decadence Vico defends it against the attacks of modern political thinkers for whom monarchy represents an early barbaric form of government. The fall of Rome (and paradigmatically of any other nation) is not a direct consequence of original sin; nor is Roman republic without its own merits. However human achievements cannot be definitive; the civil virtues remain man's property as long as he holds fast to the primary institutions. In the general context of the New Science this simply means the verification of the providential intervention in history to safeguard humanity and the universal order ${ }^{142}$.

Vico's conception of order and the measures advocated to maintain it resemble to a great extent to those of Augustine; in both cases order is attributed also a curative-pedagogical function ${ }^{143}$. Unlike Augustine, Vico distances himself so pointedly from the natural order that he foresees the resurgence of humanity "like the phoenix"144 thanks alone to the autopoiesis attributed to phantasy. Whereas Augustine accounts for the evil in the world by having recourse to human viciousness, and thereby liberates God of any responsibility, Vico discovers in the fallen humanity the potential to recreate itself even without the assistance of God. His position is thus close to Darwin's theory of natural selection which as Hans Blumenberg observes, constitutes a recurrent theme of the teleology of modern philosophy: disorder or chaos yields the potential to build order ${ }^{145}$. The key to human resurgence is provided in the 'surplus' meaning which human actions acquire in their execution. It is not given beforehand; neither human intentionality nor chance occurrence can explain it. Vico writes: "That which did all this was mind, for men did it with intelligence; it was not fate, for they did it by choice; not chan$c e$, for the results of their always so acting are perpetually the same"146. Free

142. Compare New Science 1104-1108, esp. 1107.

143. See above, p. 334.

144. New Science 1108.

145. Hans Blumenberg, "Ordnungsschwund und Selbstbehauptung. Über Weltverstehen und Weltverhalten im werden der technischen Epoche" (in: Helmut Kuhn \& Franz Wiedmann (eds), Das Problem der Ordnung, Meisenheim am Glan, 1962, pp. 37-57), p. 56. 146. New Science 1108. 
human actions do demonstrate regularity and constancy, and this inherent force would preserve humanity from total extinction.

\section{CONCLUSIÓN}

All the various facets of Vico's philosophy of order discussed hitherto converge to a single topic, namely the self-assertion of man. In stating how the New Science envisions it one can very well demonstrate the singularity of Vico's thought and its actuality for the contemporary world. Relying on the preceding discussion I shall expound this by indicating some points of convergence between Vico's theory of image and metaphorical knowledge.

Vico's political ethics, as we have seen, is based on an anthropology which attempts to define man by freeing him both from the dictates of determinism and the conventions of libertarianism. In fulfilling this task Vico begins by describing man historically, especially by taking into consideration the very first beginnings of humanity. Man constitutes himself thanks to autopoiesis. The self-constitution of man makes him the author of the human world thanks to a productive phantasy. What the phantasy produces is images which enable man to liberate himself from the constraints of an uncultured animality. Thus the first historical activity of man consists in the production of images or myths which ordain his behaviour and thereby engender a human society. This seemingly simple thesis which Vico wants to establish against the 'political thought of his time presages important notions pertinent to a theory of symbolic pragmatism.

With the expression symbolic pragmatism is meant the philosophical hermeneutics which attempts to integrate the dimension of experience and feeling in the process of understanding. The recourse to pragmatism makes the point that comprehensible meaning refers always back to human behaviour, and such behaviour is essentially an expression of one's life-style. Understood in this manner pragmatism signifies not merely a theory of verification - what it is commonly taken to be -, but rather a general theory of consciousness which lays emphasis on practice. Consequently, the formation of meaning is explained neither by causal nor by intentional principles of consciousness, but by reference back to the practical context of concrete situations in day-to-day life. It is the life-world which orients one where to seek the concept of praxis that constitutes the situational consciousness. In order to understand somebody it is necessary to pay attention not only to what one does but also to how 
one does it. The manner of action plays a greater role than the content. For human actions are essentially linked to expressive behaviour, and thanks to this link they mean much more than pure intentionality: Behaviour expresses attitudes which define and at the same time reveal a person. Since this is true even in the very elementary stage of bodily movement (a person can be identified from the manner one walks, for example) the transition from behaviour to attitude constitutes the source of situational meaning. And patterns of behaviour convey meaning not for being what they actually are, namely forms of self-preservation, but for what they represent, namely subjectivity. Behaviour patterns in general encompass two moments: functional and representational, both of which remain united. However, the pragmatic perspective as conceived here apprehends more than mere praxis, it points to a symbolic dimension inherent in the patterns of behaviour which escapes any formalisation. Thus pragmatism as a theory of consciousness turns out to be symbolic pragmatism ${ }^{147}$.

Vico's theory of imaginative universal and the symbolic pragmatism have much in common: both emphasize mimesis and metaphor. Studies in animal behaviour have shown that mimetic exaggeration leading to formalized ceremonies constitute the basis of symbolic communication. Symbols result from the formalisation of patterns of behaviour which cannot be reduced to mere utilitarianism. For Aristotle mimesis signifies productive representation as exemplified in dance, it is not simple reproductive imitation nor free invention. Mimesis as a form of human representation holds on to reality, but also transcends it. In accepting mimesis as a fundamental cognitive concept, it is possible on the one hand to be grounded on the practical dimension and on the other hand to draw out the meaningful moments in individual actions. The symbolic pragmatism does this in as much as it affirms the unity of action and representation achieved in mimesis, for in the case of man they go together. It is the form of expression or representation which determines what should be concretely apprehended as object. Thus even objective knowledge relies upon the symbolic pattern.

The symbolic character of pragmatic apprehension can be illustrated by an example employed by Richard Rorty in connection to metaphorical knowledge ${ }^{148}$. From the pragmatic perspective Rorty defines knowledge as restruc-

147. See Ferdinand Fellmann, Symbolischer Pragmatismus. (Hermeneutik nach Dilthey. Rowohlt, Hamburg 1991), esp. pp. 16f.

148. Richard Rorty, "Philosophy as Science, as Metaphor, and as Politics" (in: Richard Rorty, Essays on Heidegger and Others. Philosophical Papers, vol. 2, Cambridge University 
turing "of our beliefs and desires", and lists three kinds of knowledge, namely "perception, inference and metaphor". It is perceptive knowledge that I employ when I catch a friend committing a disgusting action, and thereby I am obliged to change my opinion (image) about him. Knowledge based on logical inference will be the case if hitherto unknown arguments and evidences are brought forward to explain his action. Detective stories offer a very good example for this pattern of knowledge. The case of metaphorical knowledge is different, it can be explained as follows: I have a high opinion of my friend especially for his self-less actions. But suddenly I begin to see him in a new perspective: he is a tragic figure and his actions are the results of this weakness. In this change of opinion regarding my friend neither perception nor inference plays any role. Unlike in the preceding examples the new image that I have now of my friend preserves all the attributes of the old one including his motivations. The new image emerges fully from my imagination. And it does so thanks to a new context which surpasses the motives of the other; consequently it relates him to a particular form of life. Unlike in perception and inference everything happens in my mind: in the mind of the observer. The facts remain the same, only that $I$, the observer, see the things from a new perspective. Or as Wittgenstein would put it: "I see that it has not changed; and yet I see it differently"149.

This process of a 'novel vision' can be said to be the interpretative activity meant by mimesis whose symbolic character is amply evident. And the symbol is meaningful not for what it is, but for what it represents. It concerns often with the discovery of a new aspect. Thus the criterion of representation and interpretation rests in the pregnant moment which characterizes the image. Once this moment is captured interpretation and representation turn out to be successful. In spite of the fact that the interpretative activity occurs in the mind of the observer, it is not without basis on reality: mimesis as interpretative activity does not amount to pure invention. If somebody were to say that the duck-rabbit image ${ }^{150}$ (in Wittgenstein's example) represents a snake we might doubt his faculties of judgement. Similarly reading a new aspect in images requires factual foundations. Consequently, a shift in context which enables interpretation cannot be fully free, it has limits provided by human

Press, Cambridge 1991, pp. 9-26), p. 12. Rorty does not offer an example for metaphor, but it is provided by Ferdinand Fellmann, "Interpretationismus und symbolischer Pragmatismus" (Allgemeine Zeitschrift für Philosophie, 1990, Heft 2, pp. 51-59), p. 58.

149. Ludwig Wittgenstein, Philosophical Investigations, II.xi. (Translated by G. E. M. Anscombe. Macmillan, New York 1958, p. 193e).

150. See L. Wittgenstein, Philosophical Investigations, II.xi. 
praxis. This seems to be the case which Vico argues in the New Science regarding metaphorical knowledge.

In the New Science mimesis constitutes the basic pattern of behaviour attributed to the primary actions of primitive humanity. The first humans respond to the atmospheric phenomenon thunder and lightening in mimetical bodily speech ${ }^{151}$. The very first language of humanity is mute: a language of signs and things. It is a symbolic language whose eminent expression is the myth, a product of mimetic phantasy. In Vico's understanding the first humans are ignorant, and out of their ignorance is born the image of Jove ${ }^{152}$. Thanks to this imaginative creation (metaphor) the first humans succeed in interpreting the world around them: they assign meaning to nature and the natural phenomena encountered by them, and thus create a world of their own. By emphasizing image over concept Vico alludes to an 'imagic turn' in epistemology. It is the'images not the concepts which should be regarded as the foundational terms of human knowledge. Application of this intuition to the political domain gives rise to the socio-political ethics of the New Science.

From the perspective of symbolic pragmatism Vico's emphasis on images worth attention, for images like those of Jove, Juno, etc. are effective in creating attitudes. Concrete experience teaches us that behaviour and attitudes are guided, and often determined by images, not by concepts. Images control behaviour in their capacity as orientations of action. But whence these images originate? They are immanent in behaviour itself. Images which control behaviour are images which emerge from behaviour. Autopoiesis is the principle both in conceptual knowledge and practical life. Patterns of behaviour are thus founded not on human rationality, but on poiesis. Consequently to conduct or to judge human action alone on the basis of rationality would endanger its very foundation which, in fact, amounts to what the barbarism of reflection in Vico's opinion perpetrates. The passionate defence of the irrational thus enables the New Science to go beyond the conceptual realm, and to point to a more profound human dimension without which society cannot survive.

Peter G. Pandimakil

Estudio Teológico Agustiniano

Valladolid

151. The first men "expressed their very violent passions by shouting and grumbling, they pictured the sky to themselves as a great animated body, which in that aspect they called Jove, ..., who meant to tell them something by the hiss of his bolts and the clap of his thunder". New Science 377; see also $401 \mathrm{ff}$. Compare above p. $354 \mathrm{f}$.

152. New Science 376. 